\title{
Article \\ Economic Growth, Increasing Productivity of SMEs, and Open Innovation
}

\author{
Batara Surya $^{1, *}$, Firman Menne ${ }^{2}$, Hernita Sabhan ${ }^{3}$, Seri Suriani ${ }^{4}$, Herminawaty Abubakar 5 \\ and Muhammad Idris 5
}

1 Department of Urban and Regional Planning, Faculty of Engineering, Bosowa University, Makassar 90231, Indonesia

2 Department of Accounting, Faculty of Economic and Business, Bosowa University, Malassar 90231, Indonesia; firman@universitasbosowa.ac.id

3 Department of Economic, STIM Lasharan Jaya, Makassar 90231, Indonesia; nitazafio62@gmail.com

4 Department of Financial Management, Faculty of Economic and Business, Bosowa University, Makassar 90231, Indonesia; serisuriani06@gmail.com

5 Department of Economic Management, Faculty of Economic and Business, Bosowa University, Makassar 90231, Indonesia; herminawati.abubakar@universitasbosowa.ac.id (H.A.); idrismuh1955@gmail.com (M.I.)

* Correspondence: batara.surya@universitasbosowa.ac.id
Citation: Surya, B.; Menne, F.;

Sabhan, H.; Suriani, S.; Abubakar, H.; Idris, M. Economic Growth,

Increasing Productivity of SMEs, and

Technol. Mark. Complex. 2021, 7, 20.

https: / / doi.org/10.3390/joitmc7010020 Open Innovation. J. Open Innov.

\begin{abstract}
The empowerment of small and medium economic enterprises will drive economic growth. The purpose of this study is to analyze (1) how economic growth works as a determinant of increasing the productivity of small and medium enterprises; (2) the influence of government policies, business capital support, and the strengthening of human resource capacity on the development of small and medium enterprises (SMEs); and (3) strategies to increase business productivity and the sustainability of SMEs. We used a sequential explanatory design, which is a combination of quantitative and qualitative research, and data were obtained through observation, in-depth interviews, surveys, and documentation. The results of the study indicate that economic growth coupled with technological innovation will boost the productivity of economic enterprises and increase people's welfare. Government policies, business capital support, and human resource capacity strengthening simultaneously have a positive effect on the development of SMEs, with a determination coefficient of $97.6 \%$. Based on the results of this study, an economic growth strategy based on technological innovation is recommended for government decision making as an effort to increase the productivity of community economic enterprises in Makassar City, Indonesia.
\end{abstract}

Keywords: economic growth; business productivity; public welfare; economic business sustainability

Received: 11 December 2020

Accepted: 4 January 2021

Published: 7 January 2021

Publisher's Note: MDPI stays neutral with regard to jurisdictional clai$\mathrm{ms}$ in published maps and institutional affiliations.

Copyright: $\odot 2021$ by the authors. Licensee MDPI, Basel, Switzerland. This article is an open access article distributed under the terms and conditions of the Creative Commons Attribution (CC BY) license (https:// creativecommons.org/licenses/by/ $4.0 /)$.

\section{Introduction}

Development policies that are oriented towards regional economic growth supported by the use of technology will accelerate and encourage increased productivity in economic enterprises developed in the community. Community economic development through entrepreneurship training has an impact on economic growth, and efforts to increase community productivity will require technological innovation [1]. The dynamics of the global economy have a significant impact on the economic structure of the region, including the SMEs [2]. Political stability and security play an important role in economic growth. This means that the components of political stability, socio-economic conditions, and investment have a positive effect on the flow of capital and investment in a country, including small and medium enterprise development [3]. Furthermore, industrialization and modernization followed by conducive investment flows are determinants of regional economic growth in Indonesia [4]. Thus, technological innovation followed by political stability leading to industrialization and modernization will accelerate economic growth and increase the productivity of community economic enterprises [5]. 
Economic growth in several countries in Southeast Asia during the 2018-2019 period grew by an average of $4.6 \%$. The highest economic growth was experienced by Cambodia and Vietnam, with respective values of $7.1 \%$ and $6.9 \%$ [6]. There are 63 million SMEs developing in Indonesia, 62 million of which are categorized as medium enterprises and 750,000 of which are categorized as small businesses. Thus, SMEs have the potential to boost national economic growth in Indonesia. Furthermore, if these business ventures are developed and improved, the Indonesian economy will experience a growth rate of 5\% [7]. This means that developing SMEs will contribute $60 \%$ of Indonesia's total gross domestic product (GDP). The existence of MSMEs in Indonesia is still faced with a very basic problem, namely weak access to formal financial institutions, especially access to capital loans from banks, which only reach $20 \%$ of the total loans disbursed. Thus, the characteristics of small and medium business management are still not conducive to maximum benefits due to various policy problems that still require complex procedures and requirements [8].

In the context of regional growth at a macro level, support for the existence of economic enterprises, especially SMEs, needs to be oriented towards creating competitiveness and business productivity that is competitive in global, national, and local markets. Thus, it requires increased knowledge, good management, and a strengthening of human resource competencies. That is, the key element of the sustainability of an economic enterprise is the ability to read the strategic environment and be competitive $[9,10]$. Economists believe that the achievement of high economic growth, which is most often measured in GDP (Gross Domestic Product), not only reflects wealth, social welfare, and the ability to develop entrepreneurship, but is also important for balancing economic, environmental, and social development on an ongoing basis [11,12]. Furthermore, in the context of local and regional development, relational assets are important in strengthening the capacity of business institutions, network systems, and business cooperation as a single system [13,14].

The acceleration of the development of Makassar City towards industrialization and city modernization is marked by an economic growth of $10.2 \%$. Five strategic economic sectors contributed positively to Makassar City's Gross Regional Domestic Product in 2019: (1) wholesale trade, retail, and car and bicycle repair, with a contribution value of $20.46 \%$; (2) construction services, with a contribution value of $18.22 \%$; (3) the processing industry, with a contribution value of $10.31 \%$; (4) educational services, with a contribution value of $8.77 \%$; and (5) information and communication, with a contribution value of $9.08 \%$ [15]. These five sectors confirm that the macroeconomic growth of Makassar City is relatively stable but has not been able to encourage an increase in SMEs in relation to business innovation and sustainable employment absorption. This condition is influenced by several factors, including (1) the weak process of developing SMEs, (2) the innovation and utilization of technology that has not been optimized to support the development of SMEs, (3) support for business capital and access to formal finance to support increased production, a diversity of economic enterprises, and product marketing systems that are not yet optimal and sustainable, and (4) government policy support that has not been optimal for SMEs.

Research results that support this study include: (1) studies conducted by Munizu [16] affirmed that hard and soft technology resources play an important role in encouraging the increased productivity of economic enterprises in relation to organizational arrangements. (2) Studies conducted by Smith [17] found that the technological innovation capability of an economic enterprise is an integration of all existing resources in one company. (3) Studies conducted by Hsien Wang et al. [18] found that the ability of technological innovation is directly related to five indicators, namely, (i) the ability to read opportunities, (ii) innovation in making decisions, (iii) ability in marketing, (iv) production capability, and (v) capital capability. (4) Studies conducted by Xirogiannis et al. [19] found that the relationship between human resource competence and the performance of SMEs was influenced by human resource competency factors, namely, knowledge, skills, and the ability to improve business performance. The results of these studies are at a meeting point in the sense that SMEs will be productive when followed by the ability of human resources and technological 
support to encourage increased business performance. The continuation of the study is more focused on increasing the productivity of SMEs, which is followed by the use of technology, strengthening the capacity of the workforce, support for business capital and support for market access from the government, which will encourage economic growth, increase welfare, and reduce socio-economic disparities towards increasing the productivity of small and medium businesses on an ongoing basis.

Furthermore, increasing the productivity of SMEs in Makassar City is very important and strategic to support economic growth, absorption of labor, and increase community welfare. The focus of this study is aimed at answering the following research questions: (1) How does economic growth work as a determinant of increasing the productivity of small and medium enterprises? (2) How do the influence of government policies, business capital support, and human resource capacity affect the development of SMEs? (3) What is the strategy for increasing business productivity and the sustainability of SMEs?

\section{Conceptual Framework}

The dynamic development of Makassar City illustrates that the macroeconomic growth orientation has made a positive contribution to the Gross Regional Domestic Product but has not been able to encourage the improvement of the micro economy and the small business sector driven by SMEs. Gross Domestic Product (GDP) is a measure of total production in relation to the monetary value of all goods and services produced in a region for a given period of time [20]. This means that macroeconomic stability tends to be stable if it is not faced with serious problems, such as disease outbreaks that disrupt the social stability of the community, in relation to the decreasing purchasing power, as well as the distribution patterns of the flow of goods and services. Thus, macroeconomic growth tends to be stable if it is followed by enough public confidence in government policies. The conceptualization of macroeconomic theory holds that sustainable development is an effort to permanently maintain income, which results from a reduced capital stock [21,22]. This means that capital flows are a key variable in supporting the sustainability of economic growth both for the country and in the regional context [23,24].

In the context of regional development, the macroeconomic concept is basically oriented towards efforts to promote fair and equitable economic growth through the use of natural resources $[25,26]$. Development policies and financing are designed to address income inequality and socio-economic inequality [27]. Thus, widening income inequality will have an impact on the economic order, political unrest, and social problems in a country and region $[28,29]$. This means that inequality and socio-economic disparities contribute to weak consumption levels, leading to an increase in the poverty rate. One of the government's efforts to overcome this problem is the development of SMEs through a simplified licensing facility, in the hope that more economic enterprises will develop, and which has the opportunity to legalize economic activities in the community [30,31]. Thus, an increase in the productivity of community economic enterprises in Makassar City will be achieved if it is supported by government policies and an ease of licensing for the community in relation to the development of SMEs.

One effort made by the Indonesian government to encourage increased economic growth and the optimization of business ventures developed in the community has been to simplify the licensing process through the use of online single submission (OSS). The use of OSS is expected to encourage technological innovation efforts so that entrepreneurs can survive, continue to produce, and drive the national economy. OSS is a business licensing system that is integrated electronically with all ministries and state agencies to all local governments in Indonesia. Thus, the implementation of an OSS policy is an effort to improve the national economy and the growth of the business world, especially SMEs, which have been complaining about the length of time required, and the bureaucratic chain that must be passed, to start a business. Technological innovation is important in supporting economic activities in the community for increasing productivity and modern business management $[32,33]$. The study's conceptual framework is presented in Figure 1 below. 


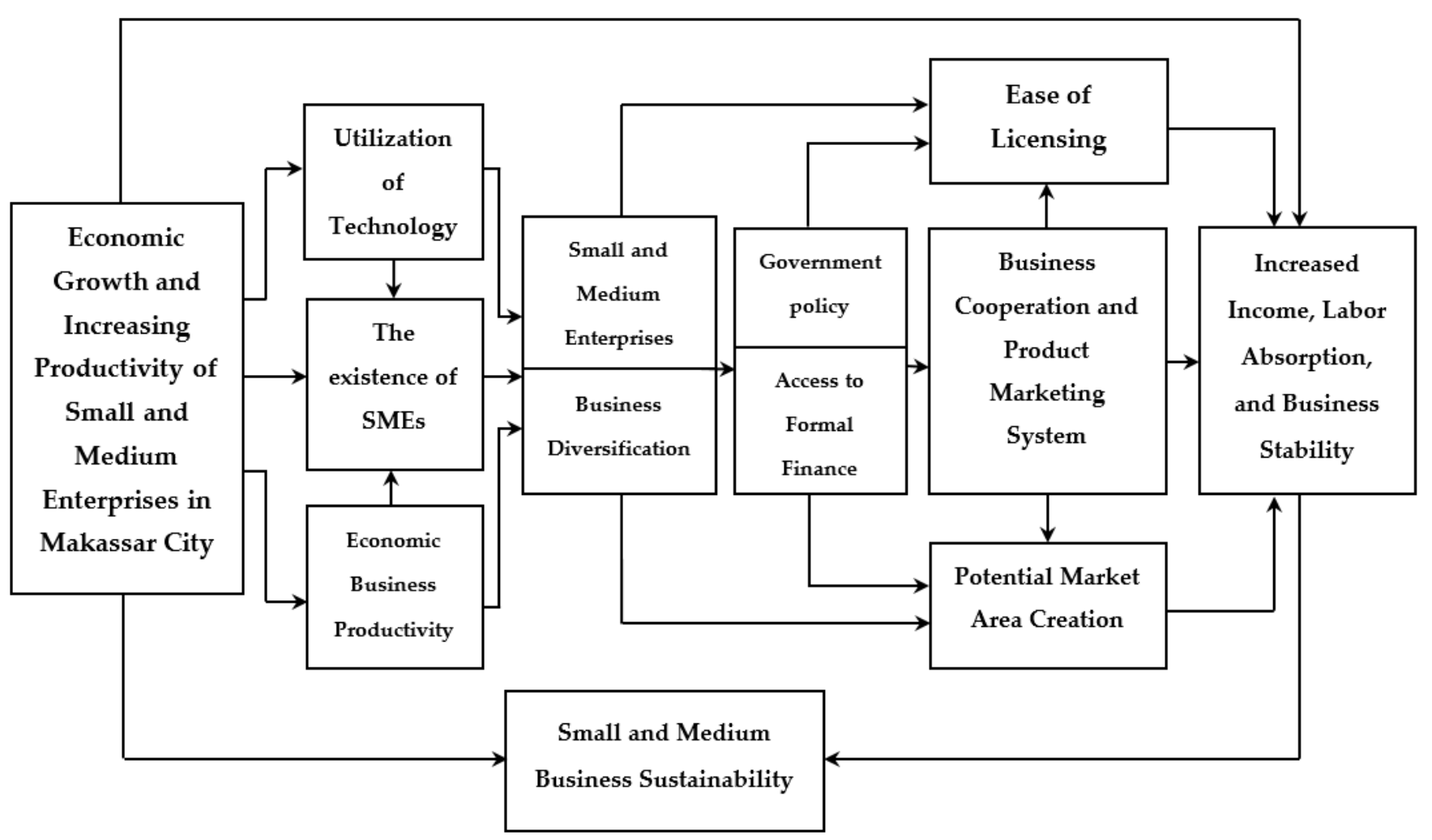

Figure 1. The conceptual framework of economic growth, technological innovation, and community economic business sustainability. Source: author's elaboration.

\subsection{Economic Business Productivity}

The era of globalization with technological advances indeed entails a demand to support regional and national economic growth. In general, globalization is seen as a process of global dependence driven by capital and investment towards market integration and competition, which requires deregulation $[34,35]$. In this context, it can be understood that the progress of development and economic growth of Makassar City cannot be separated from the impact of globalization and technological advances, which play a strategic role in supporting the performance of SMEs developed in the community. Five important and strategic roles in the use of technology support the development of SMEs include the following: (1) changing manual processes to automatic ones, reducing labor costs and operating costs; (2) reducing the time needed to perform tasks; (3) increasing the speed of decision making and increasing competitive economic business performance; (4) saving costs on promotion and marketing; and (5) integrating the system from process to product marketing. Thus, the function and role of technology will accelerate the transformation of the business world, including SMEs developed in the community. Thus, the use of technology is a driver of business sustainability, digital transformation, and entrepreneurship [36].

\subsection{Sustainability of SMEs}

Technology has become important for business competition and has penetrated all aspects of business life. This means that technology is a strategy in dealing with ongoing developments in an era of globalization and digitalization. The impact of globalization is characterized by the mobility of goods and services, capital flows, and the use of technology [37]. Furthermore, in order to face the global market competition, business enterprises that can master technology are needed. This means that the technological components owned by a business must be continuously updated to compete in product marketing and reach potential markets. Thus, product advantages, market potential, the fulfillment of customer needs, human resource capacity, the mastery of technology, 
and the utilization of resources are factors that affect the performance of economic enterprises [38]. This means that business competitiveness, business productivity, management, raw materials, production costs, technology, leadership transformation, trust and innovative employee behavior systems contribute positively to the existence of companies including SMEs $[39,40]$. The development of SMEs through technological innovation that develops in the community in Makassar City is expected to expand market reach and the process of accelerating structural transformation. This indicator is measured based on changes in the economic structure of Makassar City and the resilience of the national economy in Indonesia.

The issue of sustainability has triggered the birth of new ideas about the concept of economic development in relation to environmental and social aspects. Sustainable development has become a fundamental strategy for guiding social and economic transformation [41,42]. Furthermore, small and medium business governance in Makassar City is faced with new challenges, namely, in terms of business sustainability. Business continuity is related to three basic components, namely, profit, people, and the planet. This means that it requires the use of environmentally friendly technology and the development of clean products [43]. Furthermore, the strategy to increase profit, people and planet can be carried out in a simple way, namely waste management with the Garbage Bank system, product innovation from recycled materials, paperless online promotion, the use of environmentally friendly product packaging, reducing the use of equipment that consumes relatively large amounts of energy, and apportioning some business profits towards social responsibility. The aim is to ensure the sustainability of SMEs and social cohesion in society.

\section{Materials and Methods}

\subsection{Research Design}

This research uses a sequential explanatory strategy approach, a strategy applied by collecting and analyzing quantitative data first and qualitative data second. First, the pre-field stage included (i) a description of the research design, (ii) a literature review, (iii) a selection of research objects, (iv) a list of research instruments used, (e) a description of the data collection design, (f) a description of the data analysis procedure design, and (g) an explanation of data validity. Second, in the field stage, the researchers identified SMEs that needed support with increasing business productivity, technological innovation, coaching, business capital, product development, and business product marketing. The ontological assumption here is that the government will support increases in the productivity of SMEs for the economic growth of Makassar City.

Third, upon entering the field, the researchers studied the situation and the conditions of SMEs developed in the community in Makassar City. The aim was to improve the relationship between the researchers and the subjects under study. Fourth, in the data collection process, researchers (i) limited themselves to the scope of the study, (ii) recorded data using field notes, (iii) collected data using a recording device, (iv) examined contradictory situations, and (v) conducted field analysis. Thus, in this study, data analysis began with field data collection, which was then grouped according to the focus and objectives to be achieved. The grouped data was used for interpretation or verification using the theoretical basis used in this study.

\subsection{Study Area}

This study was conducted in Makassar City through the identification of SMEs, which are scattered in several sub-district locations. The selection of SMEs developing in Makassar City was based on the following considerations: (1) Does the SME require an increase in business productivity based on technological innovation? (2) Does the SME require fostering and product development efforts to reach potential markets? (3) Does the SME need business capital support to seize market opportunities and workforce absorption in order to reduce the unemployment rate of the working age population? 
These indications were assessed based on the ability to survive and maintain economic business stability. The number of SMEs in the developing city of Makassar was 2683 divided into several categories, namely, (i) food and beverage businesses, (ii) handicraft businesses, (iii) the creative economy, (iv) clothing, and (v) cafes and restaurants. Furthermore, the sectors of economic activity and their contribution to the Gross Regional Domestic Product of Makassar City for the period 2017-2019 are presented in Table 1 below.

Table 1. Gross Regional Domestic Product of Makassar City in 2017-2019.

\begin{tabular}{|c|c|c|c|}
\hline \multirow{2}{*}{ Business Field } & \multicolumn{3}{|c|}{ Economic Contribution (Year) } \\
\hline & 2017 & 2018 & 2019 \\
\hline Agriculture, Forestry, and Fisheries & 793,150 & 808,428 & 854,968 \\
\hline Mining and Excavation & 1242 & 1102 & 991 \\
\hline Processing Industry & 28,442 & 29,380 & 32,666 \\
\hline Procurement of Electricity and Gas & 43,855 & 50,468 & 54,824 \\
\hline Water Supply, Waste Management, Waste, and Recycling & 284,373 & 307,684 & 306,466 \\
\hline Construction & 24,591 & 28,760 & 32,513 \\
\hline Wholesale and Retail Trade, Car, and Motorcycle Repair & 27,216 & 31,753 & 36,513 \\
\hline Transportation and Warehousing & 3684 & 4151 & 4588 \\
\hline Provision of Accommodation, Food, and Drink & 3224 & 3698 & 3980 \\
\hline Information and Communication & 12,848 & 14,801 & 16,204 \\
\hline Financial Services and Insurance & 8823 & 9706 & 10,375 \\
\hline Real Estate & 5569 & 5957 & 6378 \\
\hline Company Services & 1660 & 1897 & 2163 \\
\hline Government Administration & 4683 & 5494 & 6090 \\
\hline Education Services & 12,825 & 14,484 & 18,164 \\
\hline Health Services & 3967 & 4483 & 5020 \\
\hline Other Services & 3809 & 4470 & 5067 \\
\hline Total Gross Regional Domestic Product & 143,148 & 160,207 & 178,430 \\
\hline Growth Rate (\%) & & 11.58 & \\
\hline
\end{tabular}

Source: author's elaboration and BPS Makassar City [15].

Table 1 illustrates five business fields that have a dominant contribution value to the economic growth of Makassar City: (1) wholesale trade, retail, and car and bicycle repair, with an average growth of $5.56 \%$; (2) the processing industry, with an average growth of $1.10 \%$; (3) construction services, with an average growth of $5.65 \%$; (4) information and communication, with an average growth rate of 5.07\%; and (5) financial and insurance services, with an average growth of $3.34 \%$. These five fields confirm that the economic growth orientation of Makassar City still relies on trade, industry, construction services, information and communication services, and financial and insurance services. Thus, the economic growth of Makassar City has not been matched by its SMEs.

The potential for developing SMEs in Makassar City is dominant in centers of economic activity in the city center and in transitional areas. Developing SMEs are spread across several districts, among others: (1) Mariso Regency, with 517 business units; (2) Mamajang District, with 81 units; (3) Tamalate District, with 157 units; (4) Makassar Regency, with 149 units; (5) Ujung Pandang District, with 364 units; (6) Wajo District, with 25 units; (7) Bontoala District, with 381 units; (8) Ujung Tanah District, with 8 units; (9) Tallo Regency, with 82 units; (10) Panakukkang District, with 176 units; (11) Biringkanaya Regency, with 63 units; (12) Tamalanrea District, with 25 units; (13) Rapoccini District, with 408 units; (14) Manggala District, with 323 units; and (15) Sangkarrang Regency, with 5 units. The study locations are presented in Figure 2 below. 


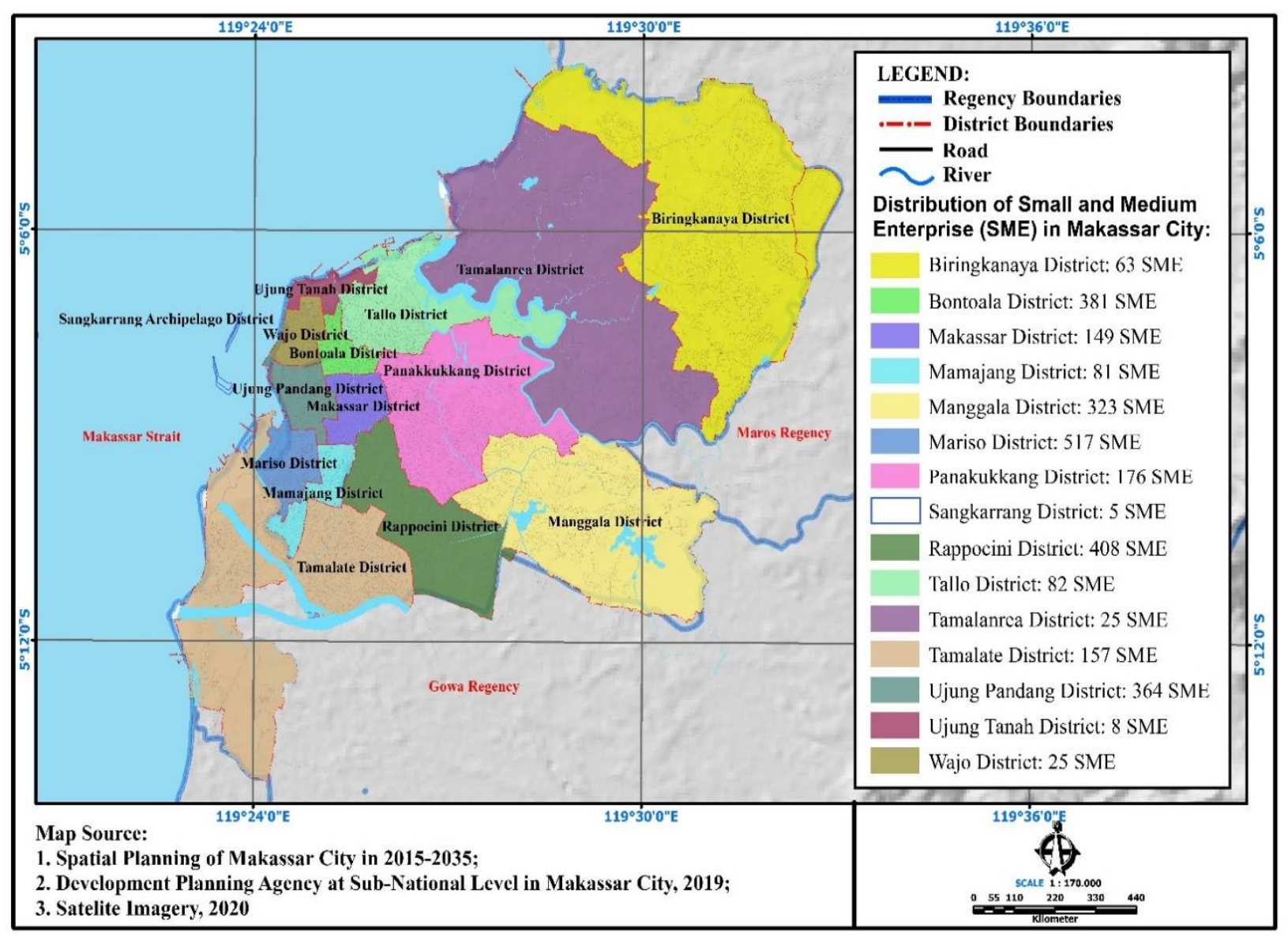

Figure 2. Small and medium enterprises (SMEs) in Makassar City as study objects. Source: author's elaboration and development planning agency at sub-national level in Makassar City.

\subsection{Data Collection}

In this study, the data were obtained through field observations, surveys, in-depth interviews, and documentation. The data sources in this study were divided into three categories: (1) Data on economic growth and technological innovation are determinants of the increasing productivity of community economic enterprises in Makassar City. The data sources are economic potential, the basic economic sector, and technology utilization obtained through observation and documentation. (2) Data on government policies, business capital support, human resource capacity, and the development of SMEs were obtained through observation, surveys, in-depth interviews, and documentation. (3) Data on economic growth, technological innovation, business diversification, product marketing, and business economic stability were obtained through observation, surveys, in-depth interviews, and documentation. (4) Data on strategies for increasing business productivity and the sustainability of economic enterprises, obtained through observation, surveys, in-depth interviews, and documentation taking, into account the strengths, weaknesses, opportunities, and threats of SME sustainability in Makassar City.

\subsubsection{Observation}

Observation was used to observe the characteristics and potential of SMEs, the business cooperation that was built, the workforce used, and the efforts of SME to maintain business stability. Furthermore, observation was also used to observe SME actors both individually and in groups for some time without manipulating or controlling them, as well as recording important findings to support the analysis process. The instruments used by researchers in collecting through observation were, among others; field notes, periodicals, 
and checklists. The aim was to describe the circumstances, situations and events related to the existence of SMEs in Makassar City.

In this study, two things were done by researchers in identifying the existence of SMEs, namely: (a) capturing the social situation and context of SMEs entrepreneurs in developing their business, and (b) identify SME activities for the purpose of comparing and assessing the different characteristics of the economic enterprises being developed. That is, researchers noted things that are factual which are considered to influence the existence of SMEs. From this information and context, the researchers then described the events observed in the field. Types of data tracked in the implementation of observations included the type of SMEs business, government policy support for SMEs development, business stability, economic relations, work systems, used business capital, number of workers, human resource capacity, technology used, management of the business, customer service, diversification of businesses, and efforts to access potential markets. The results of these observations by the researcher were then used to interpret the events that occured. That is, the researcher concluded events in the field using theoretical references, for the purpose of building research hypotheses.

\subsubsection{In-Deep Interview}

The main subjects in in-depth interviews in this study were SMEs in Makassar City. The in-depth interview functions used include: (1) a description that describes the situation and condition of SMEs in running their business, and (2) identify potentials and problems faced by SMEs actors. Thus, in-depth interviews were used to build understanding of the limited social realities of the environment as it is. The in-depth interviews in this study used instruments, namely a tape recorder and interview guides equipped with freelance notes and a checklist. Furthermore, in-depth interviews were used to trace data, namely the type of business developed, business stability, economic relations built, work systems, business capital used, number of workers, human resource capacity, technology used, business management, customer service, diversification efforts, and efforts made to access potential markets.

The interview guide held by the researcher during the in-depth interview was only used as a guide if the researcher asked a question that was further away from the substance of the research. The interview took place in an atmosphere where the informant was still carrying out his work. The information that researchers extracted and required deepening in in-depth interviews included government support, venture capital support, and the human resource capacity of SMEs. The results of the observation and in-depth interviews were then used to build hypotheses. The hypothesis developed in this study is that there is a relationship or correlation between government policy support, business capital, and strengthening human resource capacity on the development of small and medium enterprises (SMEs).

\subsubsection{Questionnaire}

The questionnaire in this study was used for two functions: (1) Description, which describes the characteristics and potential of developing SMEs in Makassar City; and (2) Measurement, which describes the relationship to the object under study. Furthermore, the purpose of using the questionnaire was to provide an overview of the potential of developing SMEs in Makassar City. The questions raised in tracing the data were respondents' perceptions about government program support for SMEs development, SMEs development needs, types of SMEs business, technology used, business diversification, venture capital, SMEs product marketing, and SMEs business stability. The data was then measured using a nominal scale and an interval scale.

Structured interviews using a questionnaire were carried out by asking questions to predetermined respondents. The filling out of the questionnaire in this study was facilitated by the enumerators who were previously selected. The enumerators were selected based on the following considerations: (1) having the ability to collect data; and (2) understanding 
the conditions of SMEs business in the study area. Before carrying out their duties in the field, the enumerators were given instructions and exercises in filling out the questionnaire as well as techniques for conducting interviews with respondents. Furthermore, the questionnaire was distributed to 15 sub-districts in Makassar City that had SME businesses. The reason the researchers determined the location was based on the development conditions of SMEs, which required various efforts to encourage increased productivity of economic enterprises. The criteria for the actors who filled out the questionnaire (respondents) were (i) SMEs based on the type of business, (ii) the participants were already married, and (iii) the economic enterprises were developed by SMEs that have been running for five years.

\subsubsection{Documentation}

Documentation is secondary data, collected by researchers to complement and support analysis. The data referred to include (1) Makassar City Figures in 2019, (2) Makassar City Gross Regional Domestic Product in 2017, 2018, and 2019, and (3) the SME profile. All information obtained by researchers from the results of previous studies and data obtained in the form of documents is categorized as secondary data. That is, the data obtained by researchers is not directly obtained from primary sources but from secondary sources. Furthermore, documentation data was used during the research, including documents on the number of SMEs obtained from the Makassar City Statistics Office, SMEs profiles obtained from the Makassar City SMEs Cooperative and Empowerment Office, and other documents related to the developing SMEs in Makassar City. All of these documents are used to support data from observations, in-depth interviews, and survey results.

\subsubsection{Research Instruments}

The qualitative approach in this study is the research instrument itself, and the first step taken was data validation. A qualitative approach involves that the researcher acting as the main instrument to determine the focus of the research and select key informants as data sources. The aim was to understand the situation and condition of the developing SMEs in Makassar City. Thus, the researchers collected data, assessed the quality of the data, interpreted the data, and formulated conclusions $[44,45]$. The steps taken by researchers to increase sensitivity are through interaction with environmental stimuli that are considered significant and affect the existence of SMEs. This means that researchers interpreted economic growth and technological innovation as a determinant of the increasing productivity of community economic enterprises in Makassar City. Thus, researchers adapted themselves to all aspects and conditions of SMEs for data collection purposes and understood the economic business situation developed by the community in relation to increased productivity and diversification of the undertaking. Researchers involved themselves in the interaction process for the purpose of understanding how society responds to economic growth, technological innovation, business diversification, product marketing, and the stability of SMEs, referring to the theories used. Researchers then made conclusions based on the collected data and obtained confirmations, amendments, and improvements, and finally enhanced trust by responding to the efforts made by the community to increase business productivity and seize market opportunities.

Furthermore, a questionnaire was used to measure technological innovation, business diversification, product marketing, how to develop a business, and business stability, related to educational background and human resource competence, type of business, ways to reach potential markets, and the sustainability of SMEs. The indicators used to measure business development are (i) the capital used, (ii) the production capacity generated, and (iii) the amount of labor used. Human resource competence is measured using indicators, namely (i) mastery of technology, (ii) ability to manage a business, (iii) skills and skills of the workforce, and (iv) leadership. Product marketing is measured by indicators, namely (i) product marketing scale, (ii) ability to access technology, (iii) use of social media, and (iv) ability to build networks and cooperation between businesses. Business sustainability 
is measured by indicators, namely (i) ability to compete, (ii) ability to diversify business, (iii) ability to maintain product stability, and (iv) competitiveness of marketed products.

\subsubsection{Triangulation}

Triangulation was carried out by combining observations, in-depth interviews, and documentation used as data sources, and this was done to test the credibility of the data and understand and interpret economic growth and technological innovation as determinants of the increasing productivity of economic enterprises. The goal was to obtain consistent, comprehensive, and definitive data. The survey data were categorized as quantitative, while the data from in-depth interviews and observations was categorized as qualitative. Thus, triangulation was carried out in three stages: (i) the extension of observations, (ii) the confirmation of data sources, and (iii) the testing of the credibility of the data. The quantitative data collected through surveys include information regarding (i) economic growth, (ii) technological innovation, (iii) business diversification, (iv) product marketing, and (v) economic business stability. Furthermore, qualitative data collected through in-depth interviews include information regarding (a) how to develop a business, (b) work mechanisms, (c) product marketing, (d) labor used, and (e) factors affecting SMEs. Qualitative data collected through observations include information regarding (a) the selection of business locations, (b) the raw materials used, (c) business existence and business stability, (d) the built economic relations, (e) work systems, and (f) barriers to marketing products.

\subsubsection{Research Informants and Respondents}

Informants in this study were used for qualitative data collection. The determination of informants was done by snowballing, meaning that the researcher determined who could be interviewed based on information provided by the local government related to developing SMEs and was able to provide good information about the development of SMEs in Makassar City. The selected informants consisted of several respondents who had been previously interviewed. This determination was aimed at exploring some of the questions that were answered in the questionnaire but required a more detailed explanation. The informants referred to by the researcher are SMEs players who have succeeded in developing their business. The informant is by the researcher as an actor in the phenomenon being studied. The number of informants determined included 15 SME business actors, five outside the respondent group and 10 respondents who had been interviewed previously. The determination of the former group was chosen based on the classification of economic businesses being developed. The latter group was chosen because (1) they had problems in developing economic activities in terms of capital, labor, technology used, and product marketing, (2) the economic relationship built by informants and consumers is still ongoing in the form of symbiotic mutualism, in this case consumers are permanent and assist in promoting SMEs business products, (3) they were able to provide information about the type of business being developed, and (4) they were able to provide information on social relations, product marketing, and business stability.

Quantitative data were collected from respondents or research samples. The sample was determined using the stratified random sampling method. Sampling was performed by dividing the population into strata, selecting a simple random sample from each stratum, and combining them into a sample to estimate the population parameters. The stratified random sampling method is a sample selection method whereby the population is divided into homogeneous groups called strata, and samples are then taken randomly from each of these strata [45]. This method is used when the research population is not homogeneous or stratified proportionally, in the sense that developing SMEs are differentiated based on business classifications, business categories, and generated profits. In this case, SMEs were differentiated based on business capital, type of business, educational background, and human resource competence. The results of filling out the questionnaire were then analyzed using quantitative descriptive methods, multiple regression, path analysis, and 
percentage analysis based on frequency figures. Sampling refers to Cochran [46] with the following formulation:

$$
\mathrm{n}=\mathrm{Z}^{2} \alpha \mathrm{PQ} / \mathrm{d}^{2}
$$

where $\mathrm{n}$ is the sample, $\mathrm{Z} \alpha$ is the standard deviation for 1.96 with a coefficient value of $95 \%$, $\mathrm{P}$ is the proportion of subjects, $\mathrm{Q}$ is $1, \mathrm{P}=0.5$, and $\mathrm{d}$ is the degree of accuracy used, which is 0.15 . The number of samples in this study was determined by as many as 350 respondents.

\subsection{Data Analysis Method}

Data analysis includes organizing, sorting, classifying, coding, and categorizing the data that has been collected, including field notes, pictures, photos, and documents in the form of reports. Organizing the data is done by contradicting the business situation of the developing SMEs for the purpose of setting a theme according to the theory used. Furthermore, in-depth interviews were carried out with informants with the aim of comparing respondents' answers in order to obtain more detailed explanations from both respondents and non-respondents who had been interviewed previously. The researchers asked the informant to provide a detailed explanation regarding the type of business, the business capital used, business stability, and the sustainability of economic business.

The quantitative approach is used to multiply information by developing several questions previously collected and given alternative answers. The questions compiled by the researchers in the questionnaire are based on the results of initial observations made in the field. Data analysis was carried out in the field at the time of data collection, separating information into categories, compiling information in a story, and presenting writing qualitatively by describing the situation and conditions of developing SMEs and the efforts made to increase business productivity. The questionnaire was used to analyze the direct and indirect effects of economic growth, technological innovation, and business diversification on product marketing and the stability of people's economic enterprises. Furthermore, emic and ethics data, which are the main data in this study, are used to collect information from informants and respondents. Thus, data analysis in a qualitative approach begins with data collection in the field, and the data are then grouped according to the research objectives. The grouped data are used for the interpretation and verification of the data based on the theory used as a reference. To interpret the data in question, the characteristics of SMEs developed in the community are compared. The data are then analyzed by displaying tables and their frequency in relation to technological innovations developed to maintain the stability of the business being developed. Thus, the data analysis in this study includes data reduction, data display, and conclusions.

Data reduction was carried out with the following considerations: (1) The data obtained in the field are high in number and complex, so reduction was immediately carried out by grouping similar data. (2) The main points, themes, and patterns were selected and summarized to formulate conclusions. (3) The data that were reduced will provide an overview of the conditions and situations of developing SMEs and make it easier for researchers to collect further data related to the efforts made to increase business productivity. (4) The data was then coded on certain aspects in order to make it easier for researchers to describe the situation and conditions of SMEs according to the focus and research objectives to be achieved. After the data were reduced, the next step was to display the data: (1) Quantitative data were presented in tables and graphs to organize the data and arrange them in a pattern in order to facilitate understanding, interpretation, and analysis. (2) Qualitative data were presented in the form of brief descriptions, charts, and relationships between categories in relation to the theory used as a reference according to the focus and objectives to be achieved in this study. (3) The data were presented in text and narrative form to facilitate understanding. (4) Data were displayed using letters and numbers arranged sequentially so that the structure is easy to understand. Thus, this research is first broad but later focused. Thus, the stages of data analysis were carried out by combining qualitative and quantitative approaches, namely, domain analysis, taxonomy, components, and cultural theme analysis. 
In order to answer research questions on how economic growth works as a determinant of increasing the productivity of small and medium enterprises, we used the location quotient analysis method and shift-share analysis. Location quotient (LQ) analysis was used to determine the degree of specialization of economic sectors that take advantage of the base sector or leading sector. Meanwhile, shift-share was used to determine (1) the shift in the economic structure of Makassar City, influenced by the shift in the economy of South Sulawesi Province, (2) proportional shift growth in the gross value added of a sector compared to the total sectors in South Sulawesi Province, and (3) the differential shift or competitive position that shows the difference in the economic growth of Makassar City. The analytical formulations used are as follows:

$$
\begin{gathered}
\mathrm{LQ}=\mathrm{S}_{\mathrm{i}} / \mathrm{N}_{\mathrm{i}}=\mathrm{S} / \mathrm{N}=\mathrm{N}_{\mathrm{i}} / \mathrm{N} \\
\mathrm{R}_{1}=\left(\mathrm{S}_{\mathrm{i}} / \mathrm{S}\right) \times 100 \% /\left(\mathrm{N}_{\mathrm{i}} / \mathrm{N}\right) \times 100 \% \\
\mathrm{R}_{2}=\left(\mathrm{S}_{\mathrm{i}} / \mathrm{N}_{\mathrm{i}}\right) \times 100 \% /(\mathrm{S} / \mathrm{N}) \times 100 \% \\
\mathrm{PEK}=\mathrm{KPN}+\mathrm{KPP}+\mathrm{KPK}
\end{gathered}
$$

where (1) $S_{i}$ is the total production $i$ in the sub-region, $N_{i}$ is the total production $i$ in all regions, $\mathrm{S}$ is the entire production in the region, and $\mathrm{N}$ is the entire production in the entire region; (2) PEK is changes in city income, $\mathrm{KPN}$ is a component of provincial growth, KPP is a component of proportional growth, and KPK is a component of city competitiveness growth. We used these equations to answer the research question "How does economic growth work as a determinant of increasing the productivity of small and medium enterprises?" Furthermore, quantitative analysis was used in this study to determine the influence of $X_{1}$ (government support), $X_{2}$ (venture capital support), and $X_{3}$ (human resource capacity) on the development of SMEs. The influences between variables were tested using multiple linear regression method with the following formulations:

$$
Y=a+b_{1} X_{1}+b_{2} X_{2}+b_{3} X_{3}+\ldots b_{n} X_{n}
$$

where $\mathrm{Y}$ is the dependent variable, $\mathrm{X}(1,2,3 \ldots)$ is the independent variable, $\mathrm{a}$ is a constant value, and $b(1,2,3 \ldots)$ is the regression coefficient value. The use of a constant value is statistically carried out if the units of the variable $X$ (independent) and $Y$ (dependent) have the same unit. The value of the constant value will then be ignored assuming that changes in the $Y$ (dependent) variable will be proportional to changes in the variable $X$ (independent). Furthermore, to determine the values of ' $a$ ' and ' $b_{1}{ }^{\prime},{ }^{\prime} b_{2}{ }^{\prime}$, and ' $b_{3}{ }^{\prime}$, a multiple linear regression equation is used.

$$
\begin{aligned}
& S Y=a n+b_{1} S X_{1}+b_{2} S X_{2}+b_{3} S X_{3}+\ldots b_{n} S_{n} \\
& S X_{1} Y=a S X_{1}+b_{1} S X_{1}^{2}+b_{2} S X_{1} X_{2}+\ldots b_{n} S X_{n} \\
& S X_{2} Y=a S X_{2}+b_{2} S X_{1} X_{2}+b_{2} S X_{21}{ }^{2}+\ldots b_{n} S X_{n}{ }^{2}
\end{aligned}
$$

To calculate the values of ' $a$ ', ' $b_{1}$ ', ' $b_{2}$ ', and ' $b_{3}$ ', the multiple linear regression equation can be formulated, namely, $\mathrm{nx}-1$, where $\mathrm{nx}$ is the number of independent variables $(X)$. Furthermore, we answer the third research question, namely how to improve business productivity and SMEs sustainability strategies, using a SWOT analysis. SWOT analysis consists of strengths, weaknesses, opportunities, and threats. This analysis will logically maximize strengths and opportunities, which are simultaneously used to minimize weaknesses and threats. The SWOT analysis matrix is presented in Table 2 below. 
Table 2. SWOT analysis matrix.

\begin{tabular}{cccc}
\hline Internal Factors & \multicolumn{2}{c}{ External Factors } & Threat (T) \\
\hline & Identification of Factor & Opportunity (O) & Determine the threat factors \\
\cline { 2 - 4 } External Factors & Strength (S) & Strategy (SO) & Strategy (ST) \\
\cline { 2 - 4 } & Determine the strength factors & $\begin{array}{c}\text { Determine the program that } \\
\text { emerges by matching strength (S) } \\
\text { with opportunity (O) }\end{array}$ & $\begin{array}{c}\text { Determine the programs that } \\
\text { emerge by matching strength (S) } \\
\text { with threat (T) }\end{array}$ \\
\cline { 2 - 4 } & Weakness (W) & Strategy (WO) & Strategy (WT) \\
\cline { 2 - 4 } & Determine the factors of weakness & $\begin{array}{c}\text { Determine the emerging program } \\
\text { by matching weakness (W) } \\
\text { with opportunity (O) }\end{array}$ & $\begin{array}{c}\text { Determine the emerging program } \\
\text { by matching weakness (W) } \\
\text { with threats (T) }\end{array}$ \\
\hline
\end{tabular}

Source: Rangkuti [47].

Explanations related to SWOT analysis (see Table 2) used in this study include (1) the interaction between strength factors and opportunity factors (S-O interactions), based on the principle of "using strength to take advantage of opportunities"; (2) the interaction between factors of strength with threat factors (S-T interactions), based on the principle of "using force to avoid or overcome threats"; (3) the interaction between the factors of weakness with opportunities (W-O interactions), based on the principle of "taking advantage of opportunities" or "taking advantage of opportunities with weaknesses"; (4) the interaction between the factors of weakness with threat factors (W-T interactions), based on the principle of "minimizing weaknesses and avoiding threats". The grouping of strategic issues can be divided into four categories: (1) S-O interactions, commonly called the "aggressive strategy", which will generate strategic issues in the comparative advantage group, which is the advantage of SMEs; (2) S-T interactions, commonly known as the "action diversification strategy", which will generate strategic issues in the mobilization group, which are efforts to mobilize the power possessed; (3) W-O interactions, commonly known as the "stabilization strategy or rationalization strategy", which will produce two possible options: doing something (investing) or doing nothing (divesting); and (4) W-T interactions, commonly called "defensive or survival strategies", which can control losses or avoid possible destruction. The process of combining the qualitative and quantitative research in this study is illustrated in Figure 3 below.

\section{Results}

\subsection{Determinants of Economic Growth and Technological Innovation}

The economic growth of Makassar City illustrates that the achievement of development targets has not been able to boost the productivity of community economic enterprises in a sustainable manner. SMEs are crucial for local economic development, playing a noteworthy role in job creation, poverty alleviation, and economic growth $[48,49]$. These indicators are reviewed based on the following: (1) government regulations, policies, and programs have not directly contributed to the empowerment of SMEs; (2) limited management resources, technological innovation, institutions, and access to potential markets; and (3) a legal and political framework is absent, which is an important basis for the empowerment of SMEs, especially the micro business sector. These three things prevent SMEs from positively contributing to economic growth and to Makassar City's Gross Regional Domestic Product.

There are a high number of laborers without adequate employment opportunities and thus there is increasing unemployment. Thus, it is likely that it will be difficult to achieve long-term economic and social outcomes [50]. Thus, creativity and technological innovation efforts are needed in the development of SMEs supported by government policies. The Industrial Revolution and the global economy have advanced rapidly due 
to technology. Furthermore, technological advances have a positive effect on economic growth, productivity, and opportunities for new business development towards modern economic business activities [51,52]. This means that technological innovation will encourage increased productivity in SMEs. Economic activity sectors that are expected to absorb productive labor in Makassar City are presented in Table 3 below.

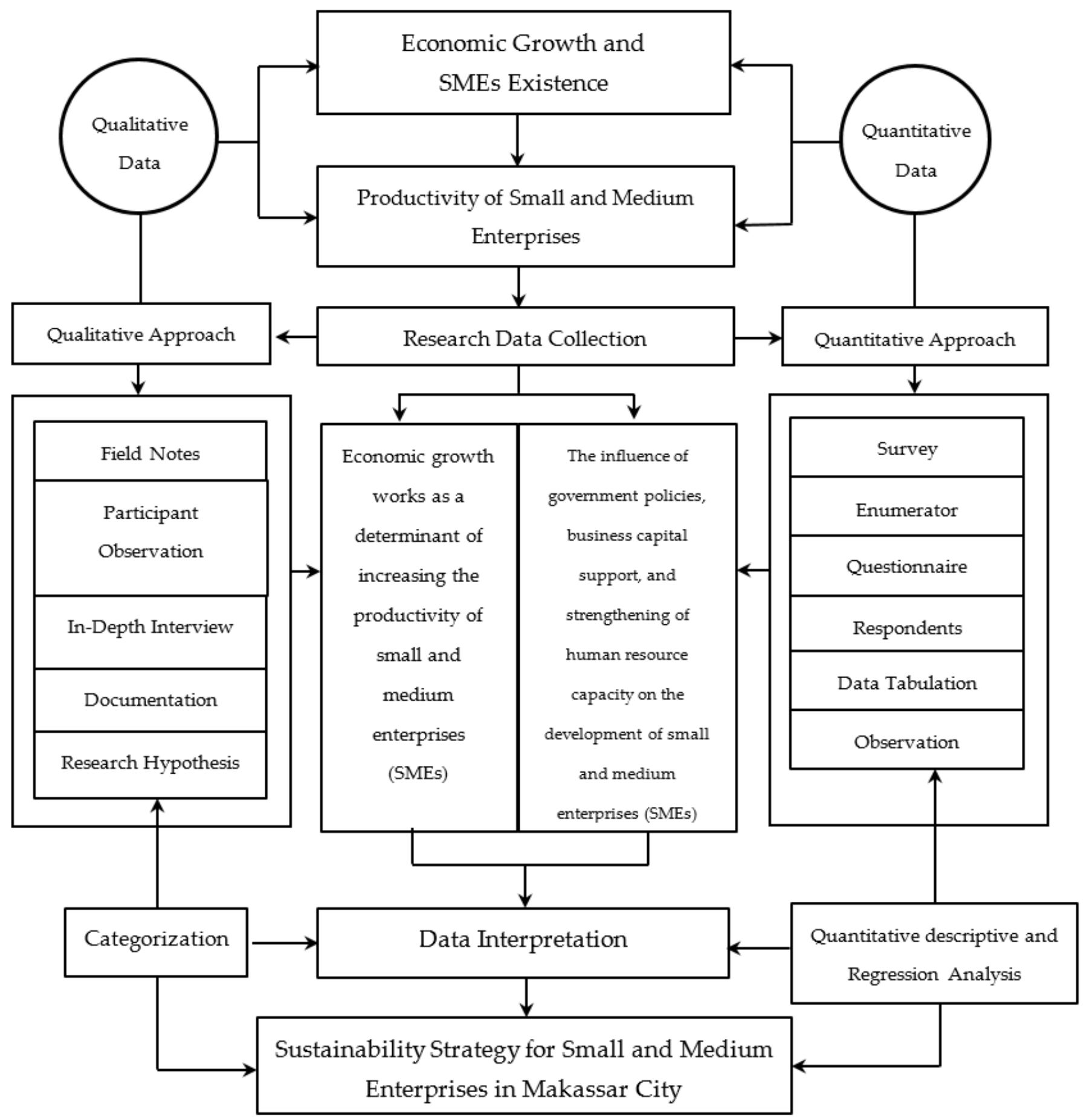

Figure 3. The process of combining qualitative and quantitative approaches. Source: author's elaboration. 
Table 3. The basic and non-basic economic sectors of Makassar City.

\begin{tabular}{|c|c|c|c|c|}
\hline Number & Business Field & Growth (\%) & $\begin{array}{c}\text { Location } \\
\text { Quotient (LQ) } \\
\text { Value }\end{array}$ & Information \\
\hline 1 & Agriculture, Forestry, and Fisheries & 5.76 & 0.046 & Non-Base \\
\hline 2 & Mining and Excavation & -10.08 & 0.000 & Non-Base \\
\hline 3 & Processing Industry & 11.18 & 2.804 & Base \\
\hline 4 & Procurement of Electricity and Gas & 8.63 & 0.656 & Non-Base \\
\hline 5 & Water Supply, Waste Management, and Waste and Recycling & -0.40 & 2.924 & Base \\
\hline 6 & Construction & 13.05 & 0.300 & Non-Base \\
\hline 7 & Wholesale and Retail Trade and Car and Motorcycle Repair & 14.99 & 2.712 & Base \\
\hline 8 & Transportation and Warehousing & 10.55 & 1.364 & Base \\
\hline 9 & Provision of Accommodation, Food, and Drink & 7.61 & 3.021 & Base \\
\hline 10 & Information and Communication & 9.47 & 2.698 & Base \\
\hline 11 & Financial Services and Insurance & 6.88 & 3.377 & Base \\
\hline 12 & Real Estate & 7.08 & 2.088 & Base \\
\hline 13 & Company Services & 14.04 & 5.554 & Base \\
\hline 14 & Government Administration & 10.86 & 1.626 & Base \\
\hline 15 & Education Services & 25.41 & 3.694 & Base \\
\hline 16 & Health Services & 11.98 & 2.831 & Base \\
\hline 17 & Other Services & 13.36 & 4.063 & Base \\
\hline
\end{tabular}

Source: analysis results.

Our interpretations are as follows: (1) the economic base sector consists of 13 economic business fields, and (2) the non-basic sector includes four economic business fields. These results confirm that the economic growth of Makassar City can drive the economy and contribute positively to increasing regional revenue, but it has not been integrated with the SMEs developed in the community. Thus, an economic policy from the government is needed through strategic programs that favor SMEs. With the globalization of the knowledge economy, national economic growth depends ever more on the efficiency of innovation systems in stimulating the creation, dissemination, and use of knowledge. Technological innovation is the main motivation in the evolutionary process of economic structures towards economic development [53]. Furthermore, strategic efforts that can be made to support the development of SMEs in Makassar City are as follows: (1) the empowerment of economic enterprises; (2) business training and guidance towards the use of technology; (3) financial management training and business capital support through formal financial institutions; and (4) access to product marketing to reach potential markets. These will require cooperation between the government, the private sector, and business actors. The growth of the economic activity sector and its contribution to the Gross Regional Domestic Product of Makassar City is presented in Table 4 below.

Table 4. The economic growth of Makassar City.

\begin{tabular}{|c|c|c|c|c|c|}
\hline \multirow[b]{2}{*}{ Number } & \multirow[b]{2}{*}{ Business Field } & \multicolumn{4}{|c|}{ Economic Growth } \\
\hline & & $\begin{array}{l}\text { Component of } \\
\text { Economic } \\
\text { Growth }\end{array}$ & $\begin{array}{l}\text { Component of } \\
\text { Proportional } \\
\text { Growth }\end{array}$ & $\begin{array}{l}\text { Component of } \\
\text { Economic } \\
\text { Competitiveness }\end{array}$ & $\begin{array}{l}\text { Change in } \\
\text { Income }\end{array}$ \\
\hline 1 & Agriculture, Forestry, and Fisheries & $1,057,065.14$ & $-924,868.15$ & $(116,439.18)$ & $144,713.07$ \\
\hline 2 & Mining and Excavation & 2535.45 & -2437.21 & $(1335.13)$ & $(489.89)$ \\
\hline 3 & Processing Industry & $37,082,199.82$ & $-33,649,482.60$ & $(4,268,916.21)$ & $6,097,189.86$ \\
\hline 4 & Procurement of Electricity and Gas & $51,791.24$ & $-43,041.99$ & 7426.57 & $17,949.59$ \\
\hline 5 & $\begin{array}{l}\text { Water Supply, Waste Management, } \\
\text { and Waste and Recycling }\end{array}$ & $401,717.48$ & $-348,324.39$ & $(40,639.64)$ & $55,452.16$ \\
\hline 6 & Construction & $31,192,545.21$ & $196,836,957.61$ & $225,597,340.43$ & $9,175,035.17$ \\
\hline 7 & $\begin{array}{l}\text { Wholesale and Retail Trade and Car } \\
\text { and Motorcycle Repair }\end{array}$ & $33,301,407.04$ & $-25,985,279.96$ & $5,768,581.09$ & $10,844,389.58$ \\
\hline 8 & Transportation and Warehousing & $4,776,005.49$ & $-3,911,636.66$ & $239,383.12$ & $1,152,235.06$ \\
\hline
\end{tabular}


Table 4. Cont.

\begin{tabular}{cccccc}
\hline \multirow{2}{*}{ Number } & Business Field & \multicolumn{4}{c}{ Economic Growth } \\
\cline { 3 - 6 } & $\begin{array}{c}\text { Component of } \\
\text { Economic } \\
\text { Growth }\end{array}$ & $\begin{array}{c}\text { Component of } \\
\text { Proportional } \\
\text { Growth }\end{array}$ & $\begin{array}{c}\text { Component of } \\
\text { Economic } \\
\text { Competitiveness }\end{array}$ & $\begin{array}{c}\text { Change in } \\
\text { Income }\end{array}$ \\
\hline 9 & Provision of Accommodation, Food, & $4,254,246.59$ & $-3,269,843.19$ & $428,927.40$ & $1,027,590.73$ \\
10 & and Drink & $16,152,629.86$ & $-12,721,275.80$ & $2,080,467.11$ & $4,659,740.42$ \\
11 & Information and Communication & $10,880,166.30$ & $-9,30,085.98$ & $476,713.53$ & $2,875,300.57$ \\
12 & Financial Services and Insurance & $7,874,489.85$ & $-7,068,948.51$ & $(1,111,907.63)$ & $1,012,762.68$ \\
13 & Real Estate & $2,165,789.77$ & $-1,775,437.19$ & $121,757.94$ & $537,327.08$ \\
14 & Company Services & $6,731,082.21$ & $-6,079,316.11$ & $(585,154.99)$ & $1,267,812.03$ \\
15 & Government Administration & $16,637,165.49$ & $-13,639,381.72$ & $844,884.66$ & $4,038,030.98$ \\
16 & Education Services & $4,924,974.78$ & $-4,054,936.77$ & $428,832.14$ & $1,391,448.53$ \\
17 & Health Services & $4,764,170.18$ & $-3,683,495.79$ & $786,903.66$ & $1,479,045.95$ \\
\hline
\end{tabular}

Source: analysis results.

Our interpretations are as follows: (1) the dominant components of Makassar City's economic growth are the wholesale and retail trade sector and the car and bicycle repair sector; (2) the dominant proportional growth component is in the construction sector; (3) the dominant component of economic competitiveness is in the construction sector; (4) changes in the income of Makassar City are predominantly influenced by the trade, construction, processing industry, information and communication, and education services sectors.

Furthermore, increasing the economic productivity of SMEs will require an adaptation in the use of technology. Business strategy and organizational behavior require dynamic adaptation and flexibility in responding to a changing business environment $[54,55]$. Field facts that are found show that there are significant differences in various types of businesses that develop in communities that take advantage of technological innovations. This condition is marked by a shift in normative space and the rationalization of actions in developing economic business activities. The development of small business activities has a tendency, to shift, while medium enterprises have a tendency to be balanced. These two types of SMEs are then followed by the rationalization of actions. A comparison of the process of shifting normative space and the process of rationalizing actions in relation to the adaptation to technology utilization is described in Table 5 below.

Table 5. A comparison of the processes of business adaptation, shifting normative spaces, and rationalizing actions.

\begin{tabular}{|c|c|c|c|c|c|}
\hline \multirow[t]{2}{*}{ Number } & \multirow[t]{2}{*}{ Description } & \multicolumn{2}{|c|}{$\begin{array}{l}\text { The Process of Adapting to } \\
\text { Economic Enterprises }\end{array}$} & \multicolumn{2}{|c|}{$\begin{array}{l}\text { Comparison of the Shift } \\
\text { in Normative Space } \\
\text { and the Process of } \\
\text { Rationalizing Actions }\end{array}$} \\
\hline & & Small & Medium & Small & Medium \\
\hline 1 & Investment and technology development & Low & Upper & Low & Upper \\
\hline 2 & Shifting of normative space & Moderate & Upper & Moderate & Upper \\
\hline 3 & The process of rationalizing actions & Moderate & Upper & Moderate & Upper \\
\hline 4 & Efforts to increase production & Low & Moderate & Low & Moderate \\
\hline 5 & Human resource capacity and competence & Low & Moderate & Low & Moderate \\
\hline 6 & Business diversification & Low & Upper & Low & Upper \\
\hline 7 & Ability to reach potential market & Low & Moderate & Low & Moderate \\
\hline
\end{tabular}

Source: primary data and analysis results.

Table 5 provides an overview of the differences in the adaptive capacity and technological innovation of SMEs. Interpretations can be made regarding this process. First, the economic growth of Makassar City has an impact on business transformation, investment development, technological innovation, and the management of SMEs. Medium-sized 
economic enterprises are categorized as upper. This process is closely related to the support of investment, technology, modern business management, and cooperation in investment within the framework of controlling production factors based on economic motivation and business opportunities. In small businesses that are informal, the development of investment, technology, and business management is categorized as low. This condition is influenced by the ability of the business to access sources of business capital. Likewise, the investment network is also very limited, and the ability to master technology is still relatively simple. The economic business pattern that has been developed tends to be simple and aimed only at meeting subsistence needs and is more independent in nature. At the micro, small, and medium enterprise level, the transition process has a direct relationship with employment status, wages, job security, job and career mobility, participation, and satisfaction with job outcomes [56-59].

Second, the shift in normative space also shows differences in relation to the procedures for production and the business being developed. The shift in normative space in medium-sized economic enterprises is categorized as upper. This condition occurs as a result of the production procedures and work systems that are carried out contractually and collectively based on an individual's ability to reach a position. This means that position and status are largely determined by the adaptive capacity of the individual in the medium economic enterprise work system. Furthermore, in small economic enterprises, the shift in normative space is categorized as moderate. This condition occurs due to the influence of values and traditions that are still quite strong, so that the principles of togetherness and kinship are used as the basis for developing economic business. Thus, the development of a developed economic enterprise does not directly affect how production is carried out, nor does the position and status of the business tend to be constant. Even though there has been a polarization in the economy, its effect is not significant. Social polarization occurs when income inequality between groups occurs in an economic enterprise $[60,61]$.

Third, the adaptation process in relation to the economic growth of Makassar City is followed by the rationalization of actions by SMEs. In small economic enterprises, the rationalization of the actions shown is categorized as moderate. This condition occurs due to the influence of business capital and limited human resources. This means that economic efforts are developed more for prosperity and motivation. Furthermore, different conditions are shown in medium-sized economic enterprises, in the sense that mediumsized economic enterprises developed in the community are perfectly structured. Complex adaptive systems consist of a multitude of agents from whose individual adaptation efforts the adaptive behavior of the system as a whole emerges. At the level of the individual agent and the level of the system as a whole survival depends on proper adaptation to the environment $[62,63]$.

Fourth, the economic growth of Makassar City is related to efforts to increase production by SMEs. In small economic enterprises, the effort to increase production is relatively stagnant in the low category, while in medium economy businesses there is a tendency to follow market demand in the medium category. This means that business differentiation developed in the community is closely related to the ability of capital and efforts to build product marketing networks.

Fifth, the economic growth of Makassar City in relation to human resource capacity is closely related to the type of business being developed. Small economic enterprises tend to use family and relatives with inadequate educational backgrounds as workers. Meanwhile, medium-sized economic enterprises tend to utilize workers who have sufficient expertise and skills. This difference illustrates that capital capacity, business management systems, and business classifications play an important role in the use of human resources as labor in SMEs. The innovation strategy is more focused on developing business management to support increased productivity and product marketing [64]. Furthermore, innovation is the willingness to go beyond the current best conditions and pursue new opportunities, such as introducing new ideas from established practices and trying to do more than existing businesses, with new product designs being innovations for each business unit $[65,66]$. 
Thus, capital capacity, business management systems, business classifications, and human resources play an important role in business development and increasing productivity towards sustainable product marketing.

Sixth, the economic growth of Makassar City in relation to business diversification shows differentiation based on the category of community economic business types. In small economic enterprises, business diversification is in a stagnant condition and has not changed fundamentally. Meanwhile, medium-sized economic enterprises have a tendency to follow consumer demand and developing situations. They tend to build innovations based on the demands of consumer needs.

Seventh, the economic growth of Makassar City in relation to SMEs has limitations in responding to and reaching potential markets. In small businesses, a business is closely related to the ability to ensure consumer satisfaction with their products. The technology used is relatively simple, and the market potential is limited. Meanwhile, medium-sized enterprises have the ability to build networks in the product marketing system and use modern technology. Thus, the differentiation of SMEs is strongly influenced by an ability to build product marketing networks and by a mastery of technology. The actual conditions for the accumulation of capital are quite different from those prevailing for individual capital and simple reproduction [67]. The creative industry is now a topic of great publicity, not only because the industry is developing in many countries because of the industry's peculiarities that are no longer based on economic issues (low prices), but also because shifts to the creative aspect and product differentiation strategies (vertical and horizontal) affect the operational performance of the SME industry significantly and negatively [68-70].

\subsection{Government Policies in the SME Sector}

The economic structure of Makassar City is predicted to enter the recovery phase, meaning that recovery efforts will begin to move, in relation to the development of SMEs. Economic improvement is focused on five strategic sectors: tourism, micro and SMEs, labor, investment, and fisheries. The Makassar City Government also needs to resolve seven sub-sector problems related to the pandemic: (i) accommodation, (ii) food businesses, (iii) transportation, (iv) warehousing, (v) the processing industry, (vi) construction, and (vii) financial services. The assumption is that if the five sectors are able to grow positively it will boost the economic growth of Makassar City. Furthermore, two things can be developed to encourage the improvement of people's welfare: (1) human resources with high competence and (2) science and technology in line with needs. This means that human resource competence is a combination of several variables: skills, personal attributes, knowledge level, and work behavior. Problem solving competence is one of the main competencies that the community must equip during the era of the Fourth Industrial Revolution and is focused on the skills of workers needed in the context of the workplace community [71].

The formulation of development policies towards economic growth will require (1) managerial competence, which is related to (i) the ability to manage the workforce, (ii) the ability to build networks for problem solving, and (iii) powerful leaders with the ability to build communication, as well as (2) technical competence, the functional capacity for a job. The development of human resources based on the mastery of technology is directed at the development of material values, but more towards the fundamentals, namely, cultural development. This means that a mastery of science and technology will be successful if it is deeply rooted in the culture of a society. Thus, several actions are required: (a) building cooperation and being responsive to change, (b) being rational and objective, and (c) appreciating, motivating, and building a creative and innovative atmosphere. These are prerequisites for the development of high-quality and competent human resources. Further, if a company fails to properly manage and nurture employees, they may leave the company, which may have significant implications in highly sensitive areas, such as business strategy, goal achievement, company culture, and employee morale [72]. 
The development of SMEs based on technological innovation in Makassar City requires efforts to rearrange policies, including: (1) licensing and progressive manufacturing patterns that are oriented towards the introduction and mastery of superior productbased technology; (2) building technological models, mastering more advanced production techniques, and continuing a pattern of integrating technological components into new products; (3) designing new, superior products after technology integration, by building products independently; (4) determining the market, in the sense that the government provides incentives and investment for the marketing of products developed in the community, especially in SMEs. In addition, entrepreneurs are advised to form an innovation-oriented strategy to advance cultural heritage innovation, and to strengthen the accumulation of innovative resources and capabilities [73]. The functional coordination of market orientation, business culture, and the sharing economy with consumer orientation has a significant effect on product innovation, but the effect of competitive orientation on product innovation is not significant [74]. Respondents' perceptions of various programs implemented by the government to support the development of SMEs are shown in Figure 4 below.

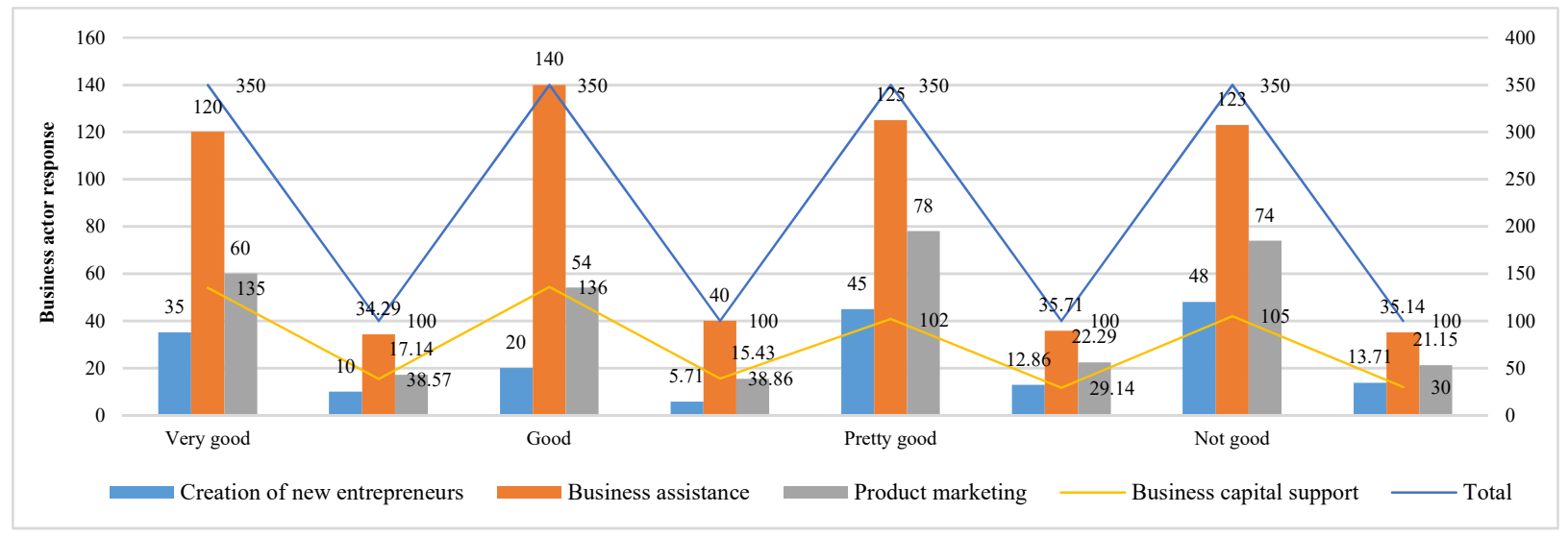

Figure 4. Respondents' perceptions of the role and support of government policies in the development of SMEs. Source: primary data.

Figure 4 shows the response of SMEs to government policies in business development. The interpretations are as follows: (1) Government policy support in terms of business capital support is $38.57 \%$. (2) Government policy support in relation to the assistance and empowerment process for SME is $34.29 \%$. (3) Government policy support in relation to the creation of new entrepreneurs is $10.00 \%$. (4) Government policy support in relation to SME product marketing is $17.14 \%$. The results of the field confirmation show that the government policies related to MSME development that have been implemented have not produced optimal results. Some of the factors that influence this condition are as follows: (1) weak coordination between agencies in managing SMEs; (2) inadequate support for human resource capacity and insufficient professionalism in managing economic enterprises; (3) a sub-optimal ability to organize SMEs; and (4) an ineffective fostering of SMEs in relation to the various programs implemented by the government. This means that the implementation of government policies has not been effective in encouraging the development of SMEs in Makassar City. Thus, the role of government is very important to integrate strategic programs towards increasing the productivity of SMEs. The mix of policy options will depend on a number of factors including societal attitudes towards entrepreneurship, the structure of the workforce, the size and role of government, the prevalence of existing levels of entrepreneurial activity, and the conditions of SMEs [75]. The responses of SMEs to the performance of programs implemented by the government are presented in Figure 5 below. 


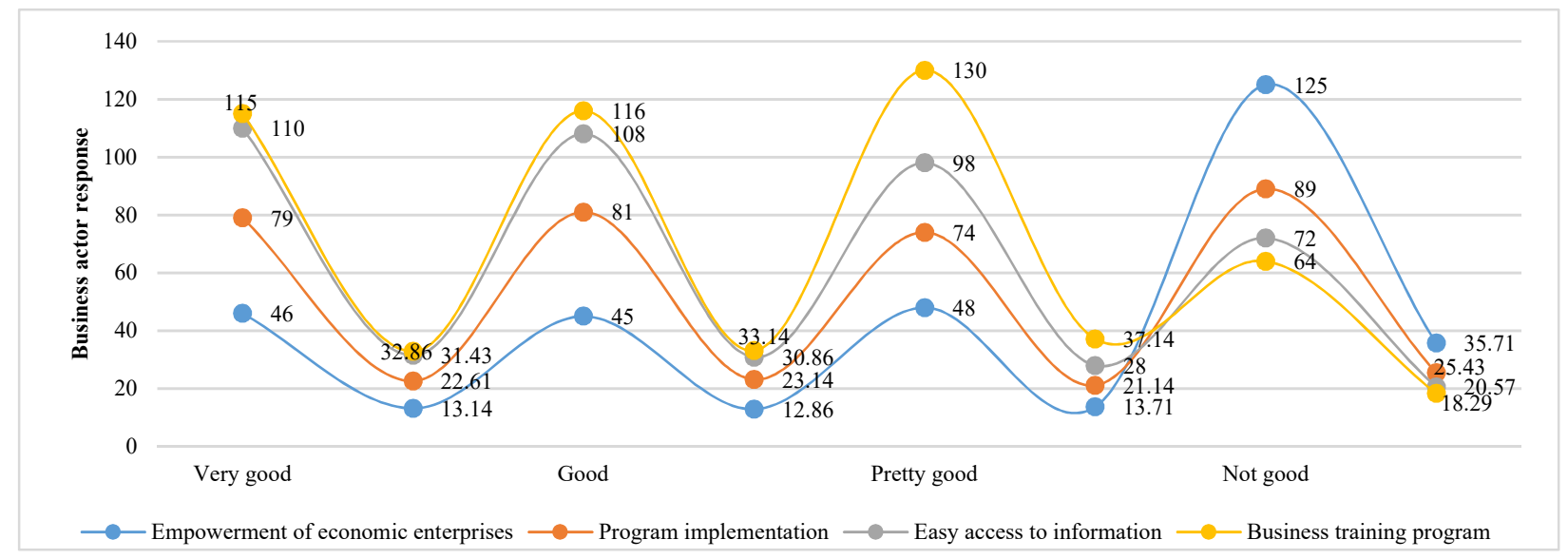

Figure 5. Respondents' perceptions of the performance of government programs in SMEs. Source: primary data.

Interpretations that can be proposed regarding the performance of government programs (Figure 5) related to the development of SMEs in Makassar City are as follows: (1) $49.42 \%$ stated that the economic empowerment of SMEs was not yet optimal; (2) $46.57 \%$ stated that the implementation of the SME development program was not yet effective; (3) $48.57 \%$ stated that it was still difficult to access information related to business opportunities; and (4) 55.43\% stated that the training programs implemented by the government were not effective in supporting the development of SMEs. Thus, the performance of the implementation of government programs to encourage the development of SMEs has not been optimal in supporting increased productivity in community economic enterprises. This means that the role of SMEs has not played an important role in supporting the economic growth of Makassar City. This means that the existence of SMEs has not been well organized, including the coaching process, which has not been carried out optimally. Unlike large corporations, SMEs have a superior flexibility to technical shifts, a higher promotion of income distribution, and better adaptability to fluctuations in the market and new customer requirements, while their organizational structure allows for quicker decision making [76]. The types of economic development and empowerment expected by SMEs are presented in Figure 6 below.

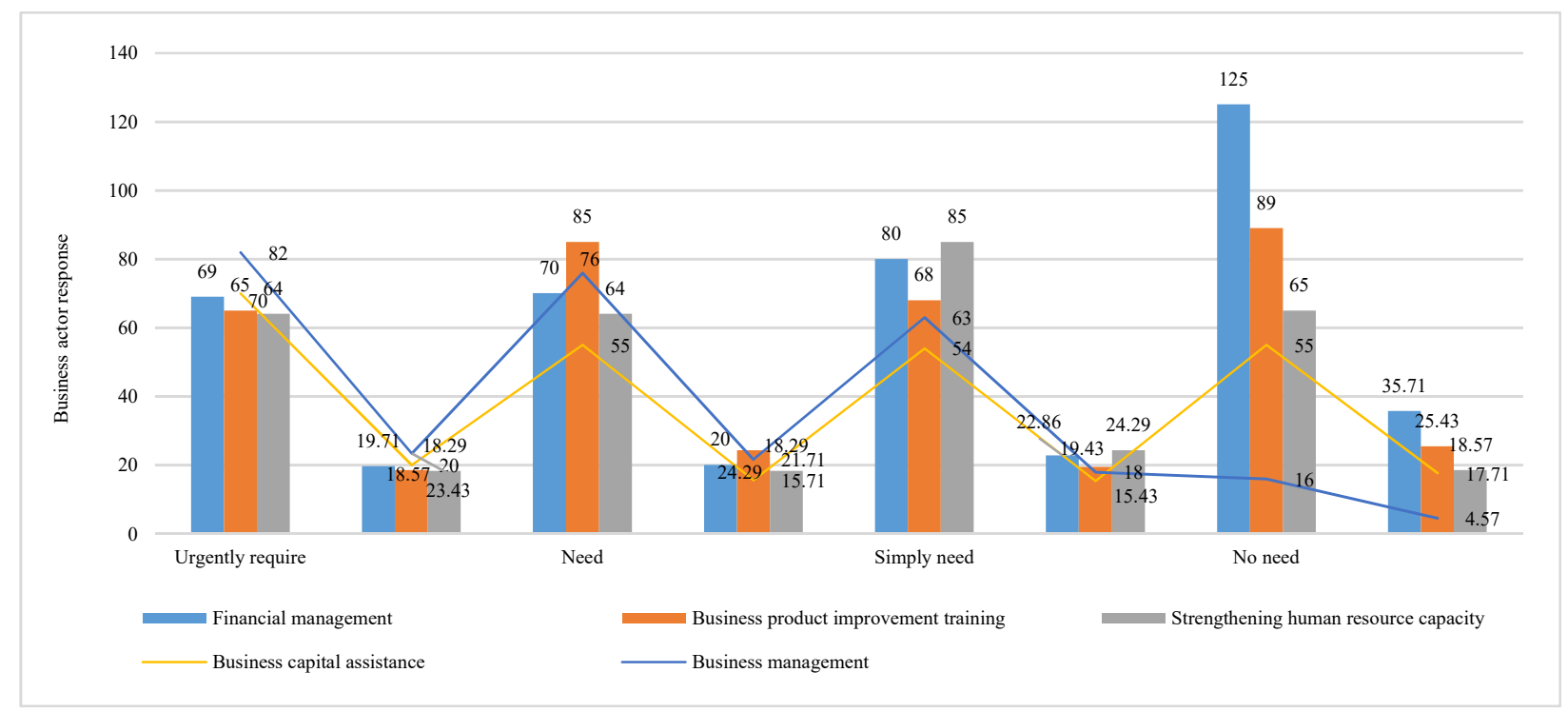

Figure 6. SMEs economic development and empowerment efforts. Source: primary data. 
Interviews related to economic development and empowerment (Figure 6) with SME entrepreneurs in Makassar City showed the following: (1) $45.14 \%$ stated that SMEs were oriented towards fostering business management; (2) $35.71 \%$ preferred business capital support for the development of SMEs; (3) 36.58\% prioritized strengthening the capacity of human resources for the development of SMEs; (4) $42.86 \%$ chose business product improvement training; and (5) $39.71 \%$ chose financial management to support the increased productivity of SMEs. Therefore, SMEs in Makassar City need stimulant support and conformity with government policies. This means that the existence of SMEs will require coaching support related to business resilience, business competitiveness, marketing strategies, and mastery of technology in the era of globalization [77]. The influence of government policies, business capital support, and strengthening human resource capacity on the development of SMEs is presented in Table 6 below.

Table 6. A summary of the test results for the significance of the regression equation coefficient.

\begin{tabular}{ccccccc}
\hline Correlated Variables & $\begin{array}{c}\text { Coefficient } \\
\text { Value }\end{array}$ & Error & t-Count & t-Table & Information \\
\hline Government policy for SME development $\left(\mathrm{rx}_{1} \mathrm{y}\right)$ & 0.192 & 0.069 & 2.873 & 1.92 & Significant \\
\hline Business capital support for SME development $\left(\mathrm{rx}_{2} \mathrm{y}\right)$ & 0.137 & 0.052 & 2.853 & 1.92 & Significant \\
\hline Strengthening human resources for the development of SMEs $\left(\mathrm{rx}_{3} \mathrm{y}\right)$ & 0.405 & 0.096 & 4.182 & 1.92 & Significant \\
\hline $\mathrm{R}$ & $\mathrm{R}^{2}$ & $\mathrm{db} 1$ & $\mathrm{db} 2$ & F-count & F-table \\
\hline 0.988 & 0.976 & 3 & 6 & 84,813 & & 4.76 \\
\hline
\end{tabular}

Interpretations of these results are as follows: (i) government policy has a positive effect on the development of SMEs, with a value of $19.2 \%$; (ii) support for business capital has a positive effect on the development of SMEs, with a value of $13.7 \%$; (iii) human resource capacity strengthening has a positive effect on the development of SMEs, with a value of $40.5 \%$; (iv) strengthening government policies, business capital support, and human resource capacity simultaneously has a positive effect on the development of SMEs, with a determination coefficient of $97.6 \%$ on SME development. Thus, SMEs will develop rapidly if supported by government policies, access to business capital, and human resource capacity strengthening. Thus, it is imperative for companies to demonstrate proactive behavior and to intensify their actions to support the achievement of a "sustainable future" [78]. Furthermore, organizations face various challenges and opportunities. However, today's business environment is changing at a faster pace than before, and organizations must constantly adapt to new conditions [79].

\subsection{Existence of SMEs}

The existence and improvement of the productivity of SMEs in Makassar City requires efforts to develop and protect their business environment. Basically, SMEs interact directly with the community, especially the middle to lower economy. Three factors cause SMEs to survive in a situation of economic uncertainty, among others: (1) community needs, in the sense that the dominant small businesses developing in Makassar City are needed by the community; (2) a cheaper selling price of products, in the sense that the sale of goods marketed is affordable by the public; (3) the absence of a direct relation to the stock index and dollar exchange rate. SMEs do not own shares, and the economic transactions that are built up do not involve dollars. This means that, even if the rupiah weakens and the stock index decreases, SMEs remain stable and run normally. Thus, SMEs integrate social and environmental goals into a business model, incorporate accountability mechanisms, and leverage and pool the resources needed to be economically competitive [80]. Furthermore, in order to support the sustainability of SMEs, it is very important to consider several principles, namely economic prosperity, community welfare, and environmental promotion in the developed business products [81]. 
Field findings show that the role of SMEs in Makassar City has not been able to increase business productivity and increase community welfare. Four factors have a positive effect on the productivity development of SMEs: (i) technology innovation, (ii) business diversification, (iii) product marketing, and (iv) business stability. The survey results on these four parameters in relation to the SMEs in Makassar City are presented in Figure 7 below.

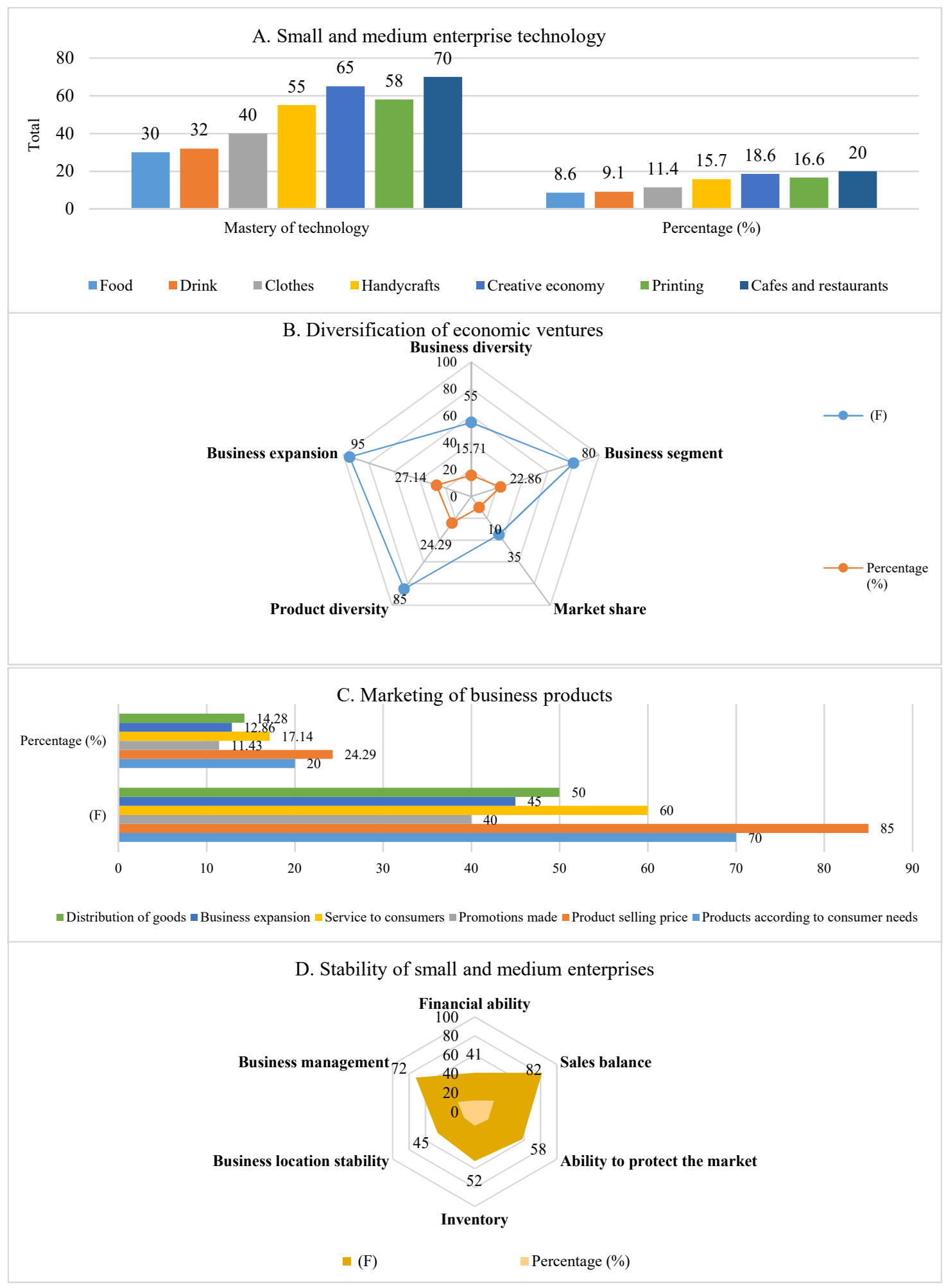

Figure 7. Examples of SMEs: (A) technological innovation, (B) business diversification, (C) product marketing, and (D) business stability. Source: primary data. 
Figure 7A shows the differences in the technological mastery of SMEs. Three types of businesses can develop technological innovation: (i) cafe and restaurant business by $20 \%$, (ii) the creative economy by $18.6 \%$, and (iii) printing businesses by $16.6 \%$. These results illustrate that technological innovation in SMEs in Makassar is still relatively low. The informants illustrate that a weak mastery of technology in SMEs is influenced by several factors, including (1) limited capabilities and expertise, (2) high operational costs, and (3) unsupportive market guarantees for developing technology-based businesses. Thus, the relatively low mastery of technology in SMEs is positively associated with business innovation and sustainable product development. Due to resource constraints and fierce competition, it is relatively difficult for small firms to achieve product innovation and gain sustainable development independently [82].

Figure 7B shows the differences in the diversification of SMEs in Makassar City. Three categories of effort increase business productivity: (i) business expansion, with a value of $27.14 \%$, (ii) product diversity, with a value of $24.29 \%$, and (iii) the development of business segmentation, with a value of $22.86 \%$. These results confirm that SMEs in Makassar City can develop business diversification and new business patterns in a sustainable manner. Thus, SMEs should start adopting more sustainable behaviors and a long-term vision to design environmentally and organizationally sustainable processes [83].

Figure 7C shows product marketing efforts undertaken by SMEs. Three interpretations can be put forward: (i) the selling price of a product needs to compete with similar products by $24.29 \%$, (ii) selling a product must be according to consumer needs by $20 \%$, and (iii) service must be given to consumers by $17.14 \%$. These results confirm that SMEs can market their products, even in limited quantities, and only need to meet local needs. Accordingly, SMEs need to adopt survival strategies and strategic methods to confront various global challenges [84].

Figure 7D shows the stability of SMEs developing in Makassar City. Three interpretations that can be proposed: (i) stability can be maintained based on an ability to manage a business, with a value of $20.57 \%$, (ii) $23.43 \%$ is determined by sales proceeds and the ability to generate profits or sales balances, and (iii) $16.57 \%$ is determined by an SME's ability to maintain market and consumer confidence. These results confirm that SMEs can maintain economic stability and the economic businesses that are developed. In most countries, SMEs play a key role in promoting sustainable economic growth and job creation [85].

\subsection{Strategy for Increasing Business Productivity and Product Marketing}

The development of SMEs in Makassar City tends to increase from time to time, but the use of technology has not been optimal for increasing business productivity and achieving optimal labor absorption. The productivity of SMEs is directly related to several factors, including (1) selection of the right location, which depends on the business being developed; (2) the use of social media, which is a strategic choice in terms of product marketing; (3) business innovation, so as to compete with other SMEs; and (4) financial planning, with a good administration system. Mistakes in financial management will have an impact on losses. Another advantage of having well-organized financial records and reports is that they can be used as supporting documents in applying for business loans. Thus, government policy support and intervention are needed for the development of SMEs, as this can help SMEs in mastering technology, improving product quality, business management, and human resource capacity strengthening [86]. Strategies for increasing the productivity and marketing of SMEs are presented in Table 7 below. 
Table 7. Strategies to increase the productivity and product marketing of SMEs.

\begin{tabular}{|c|c|c|}
\hline & Strength & Weakness \\
\hline $\begin{array}{l}\text { Internal } \\
\text { External }\end{array}$ & $\begin{array}{l}\text { - } \\
\text { economic enterprises } \\
\text { - } \quad \text { Have a stable and stable market } \\
\text { and consumers } \\
\text { - } \quad \text { The price of product marketing is } \\
\text { affordable by the community } \\
\text { - } \quad \text { Ability to survive in } \\
\text { economic situations } \\
\text { - } \quad \text { Ability to create jobs } \\
\text { - } \quad \text { Flexibility in doing business } \\
\text { Low operating costs }\end{array}$ & $\begin{array}{ll}\text { - } & \text { Limited business capital } \\
\text { - } & \text { Limited production and } \\
\text { - } & \text { Limited human resources } \\
\text { - } & \text { Business management is still traditional } \\
\text { - } & \text { Business competitiveness is still low } \\
\text { - } & \text { Access to potential markets is } \\
\text { - } & \text { still limited } \\
& \text { Productivity and business } \\
\text { diversification are still low and limited }\end{array}$ \\
\hline
\end{tabular}

\section{Opportunity}

Strategies (SO)

- Optimizing the use of funds based on product innovation and technology utilization

- Financial support from the government and formal financial institutions

- Utilization of potential raw materials

- $\quad$ Ease of access to information

- Technological innovation

- Online-based product marketing

- $\quad$ Support for strengthening business management

- Human resource training
- Effectiveness of the use of raw materials to meet market and consumer needs

- Increased productivity and technology-based product marketing

- $\quad$ Product marketing using online media

- $\quad$ Strengthening business management and product stability

- Develop new innovations and develop human resource capacity

- Strengthening the capacity of human resources and mastery of technology

\section{Strategies (WO)}

- Optimizing and increasing production capacity through business capital support from the government and formal financial institutions

- Use of local raw materials to support business productivity and business production

- Strengthening the capacity of human resources and the use of information sources in a sustainable manner

- Information technology-based business management

- Increased competence of human resources to support product competitiveness

- $\quad$ Strengthening business management and potential market access

- Diversification of business and strengthening of workforce competencies
- Competitiveness in the global market is still low

- Production capacity is still limited

- $\quad$ The scale of product marketing is still limited

- $\quad$ Promotion of business products is still limited

- $\quad$ Production knowledge and technology are still low

- $\quad$ Product models and packaging are still limited

- The use of online media for product marketing is still limited
- $\quad$ Product development and innovation followed by increased product competitiveness in the global market

- Increase in production capacity based on strengthening human

resource capacity

- Expansion of the market area through technological innovation and the use of social media

- $\quad$ Strengthening human resource skills and expertise through mastery of technology

- $\quad$ Product innovation, business expansion, and absorption of skilled labor

- Development of potential market based on the use of technology
- Increase in production capacity based on modern business management

- Build business cooperation based on strengthening institutional capacity

- Optimizing the use of human resources based on a mastery of technology

- Excellent product design to reach domestic and global markets

- Business diversification and development of production capacity to reach potential markets in a sustainable manner.

- Increased business competitiveness based on product excellence and online-based product marketing 


\section{Discussion}

\subsection{Solutions for Increasing Productivity and Marketing of SME Products}

The development of SMEs in the context of Makassar City will require government support and cooperation with various parties in various aspects to encourage increased productivity and product marketing. Several things that are needed related to efforts to maintain the stability and existence of SMEs, among others: (1) strengthening production capacity by subsidizing production tools and machines; (2) supporting business capital in the form of low interest rates and competitive tax rates, enabling SMEs to remain stable in production; (3) increasing the quality of production through tiered training efforts to improve quality in terms of product design and product forms according to business quality standards; (4) strengthening the capacity of human resources through training in terms of product management and product packaging by utilizing environmentally friendly technology; (5) production business management training to improve product competitiveness; (6) business feasibility training to obtain stimulant assistance from banks or formal financial institutions; (7) financial management support with a modern financial administration system; and (8) the protection and expansion of marketing networks through a startup-based business cooperation pattern based on the demands of consumers and potential markets. These eight processes will drive economic business growth and increase regional competitiveness through superior products that are strategic and of high economic value. Thus, business management will be strategic within the framework of independently developing SMEs towards business and implementing a sustainable business productivity strategy based on product excellence and competitiveness [87]. In the era of economic globalization, SMEs are recognized as an engine of sustainable economic development [88].

The field facts found show that limited mastery of technology, business capital, and market access have a positive contribution to the low competitiveness of SMEs and their contribution to the economic growth of Makassar City is not optimal. Thus, increasing the productivity and competitiveness of small and medium enterprises requires support for strengthening the capacity of human resources, utilizing technology and innovation through sustainable business diversification [89]. Field findings show that four factors cause the competitiveness of small and medium enterprises in Makassar City to be suboptimal in their business development, including: (i) limited business capital, (ii) low competency of the workforce, (iii) poor business management, and (iv) limited mastery of technology. Thus, small and medium enterprises will develop well if they have the ability to access potential markets through government policy support followed by innovation and business management development [90,91]. Field facts found indicate that efforts to diversify business are not optimal and the products produced are still limited, causing small and medium enterprises in Makassar City has not undergone significant changes. This means that these small and medium enterprises are still faced with challenges, namely limited access to capital, the availability of raw materials, the technology used, limited human resources, and the role of government that is not yet optimal [92]. Furthermore, in order to increase the productivity of these small and medium enterprises, it is necessary to provide guidance, business training, access to capital, and support for strategic programs from the government.

Furthermore, the efforts that need to be made to support and encourage increased productivity of small and medium enterprises in Makassar City include: (1) increasing the capacity and competence of the workforce; (2) adequate equipment support; (3) product innovation; (4) business management; (5) mastery of technology; (6) business diversification; and (7) expanding the market network. These seven things are very important to be applied towards increasing the productivity of economic enterprises and the stability of small and medium enterprises (SMEs). Thus, small and medium enterprises will make a positive contribution to economic growth and job creation [93].

In the context of product marketing, SMEs need to be supported. (1) Marketing products through the internet and social media helps SMEs to exhibit merchandise. (2) Building communication with various parties can help SMEs to determine market potential. This 
means that SMEs will be able to understand and identify the right market for the products they produce. (3) Selection of the right business location is important. The location of stalls that have business magnets that are easily accessible to potential buyers can be considered. (4) Product marketing can be achieved through influencers. Using familiar public figures can be used to introduce a trademark and to increase sales. (5) Product marketing can be achieved through affiliate marketing. Promotional efforts are carried out by building business cooperation by utilizing information technology based on online product marketing to increase the number of consumers. (6) Discount promotions can be implemented to entice users to re-order. (7) Marketing using social media can expand market networks. The seven efforts related to SME optimization will require improving product quality, human resources, digital technology-based business management, and the ability to build partnerships through startup businesses. Technological innovation is the driving force behind the industrial and business economy [94].

\subsection{Sustainability and Stability of SMEs}

Increasing the productivity of SMEs in Makassar City will require policy support from the government and is expected to reduce the unemployment rate of the working age population and play a role in economic growth. The role of SMEs is also expected to absorb labor and open up profitable business opportunities. SME sustainability is oriented towards business governance, capital support, increasing human resource capacity, and increasing competitiveness and the marketing of business products in a sustainable manner. This means that the role of SMEs will be a driving force for economic growth, an agent of change, and a pioneer in saving the environment. Thus, the role of SMEs has strategic value in encouraging regional economic growth and improving the welfare of society in general [95].

SMEs have a certain culture, and adaptability is needed in responding to healthy economic competition, so there will be resistance. This means that it is important to consider the risk of business, environmental, and social sustainability as a single system in responding to the economic growth of Makassar City. For this reason, socialization efforts are needed for SMEs related to business sustainability, protection of the business environment and efforts to create social cohesion towards increasing community welfare, increasing productivity, and preserving the environment around the business. Small and medium enterprises play an important role in reducing the unemployment rate of the productive age population [96].

The main factor that needs to be implemented to support the sustainability of small and medium enterprises in Makassar City is to build a pattern of economic cooperation between entrepreneurs and SMEs towards a synergy in the utilization of natural resource potentials effectively and efficiently. This means that the development of small and medium enterprises in Makassar City requires strategic actions, including: (1) routine guidance in relation to efforts to strengthen the capacity of human resources who have the ability to respond to market changes, (2) long-term business management oriented towards business effectiveness and efficiency, (3) the use of technology; (4) the ability to innovate, and (5) the ability to build business cooperation. Thus, the productivity of small and medium enterprises is a potential that can be relied on to spur regional growth in a sustainable manner [97]. Furthermore, in order to support the stability of small and medium enterprises, it is very important to optimize the use of information technology for product marketing, seizing business opportunities, and increasing income. These three things will have an impact on increasing economic value added for small and medium enterprises in the direction of improving service quality and expanding access to potential markets. This means that small and medium enterprises will advance and develop if they have the ability to respond to changes in the strategic environment [98].

The sustainability of SMEs in Makassar City will require several strategic steps that need to be considered: (1) manufacturing products according to consumer needs; (2) producing goods in small quantities to save costs and resources, in an effort to eliminate in-process supplies of goods and waste, by using an evenly mixed production pattern; 
(3) eliminating waste on inventory, purchasing, and scheduling using a card system in production; (4) improving the production flow and building work discipline in the business culture; (5) improving product quality by maintaining control of the production process; (6) developing financial governance, product marketing, and human resource capacity strengthening, which are cross-functional in accordance with their levels and positions; (7) eliminating uncertainty by establishing relationships in the production and marketing processes; and (8) ensuring long-term maintenance by improving quality, increasing flexibility in placing orders for goods, ordering in small quantities, and continuously orienting towards a sustainable production process. Thus, small and medium enterprises that are able to maintain product quality and efficiency in production management, have competitiveness, and have the ability to manage superior products will create economic competitiveness towards business sustainability $[99,100]$. The sustainability of SMEs in Makassar City is presented in Figure 8 below.

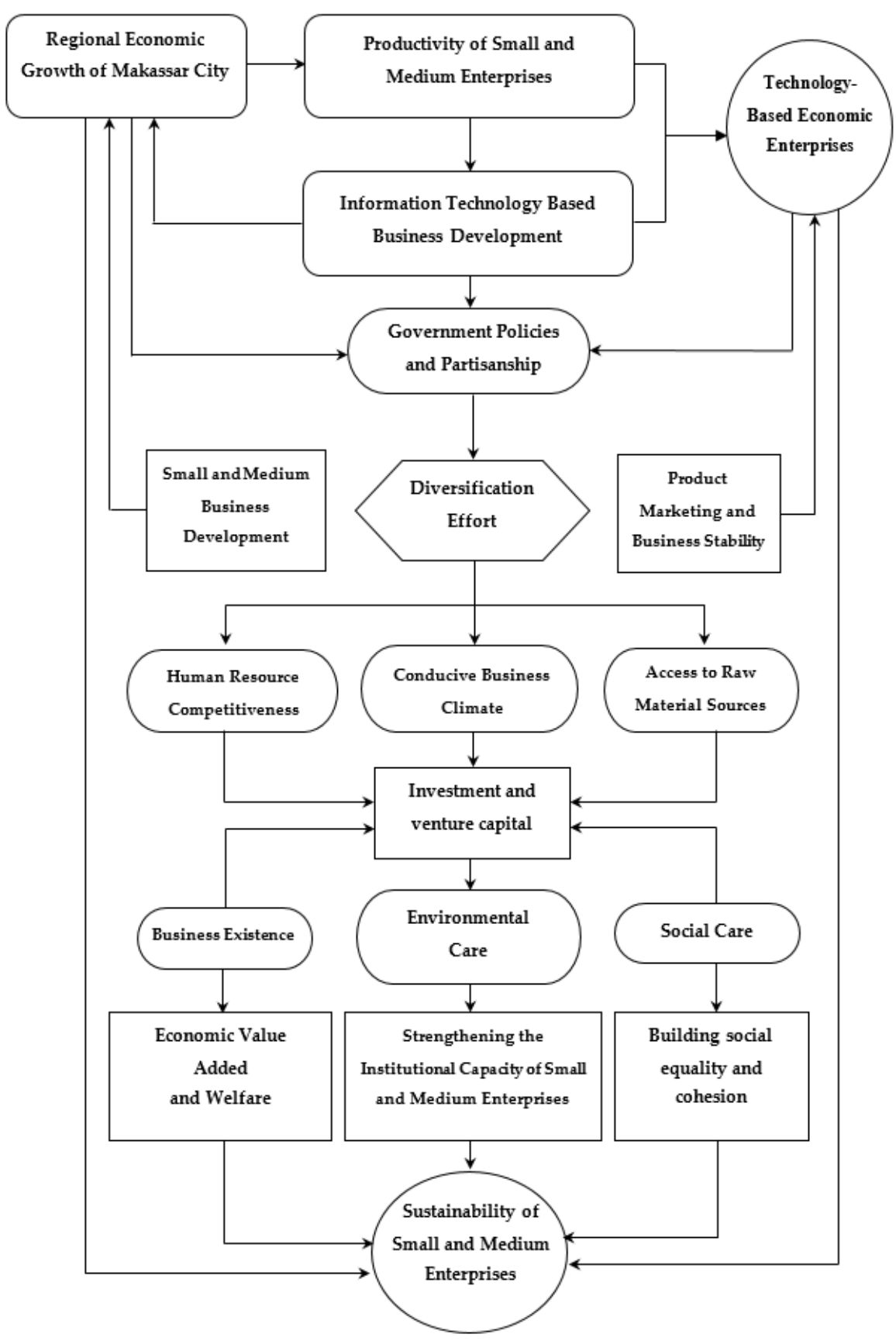

Figure 8. The sustainability of SMEs in Makassar City. 


\subsection{Open Innovation and Productivity of SMEs}

Increasing the productivity of small and medium enterprises in Makassar City will require strategic steps and policy support from the government. This government policy support is in the form of assistance in developing ideas and ideas to be adapted in the management of SME businesses. Furthermore, four strategic steps are needed to support the increase in productivity of small and medium enterprises in Makassar City, namely (i) planning, (ii) organizing, (iii) directing, and (iv) supervision. The four principles are carried out by developing new product innovations for the purpose of increasing the competitiveness of products produced by small and medium enterprises. Thus, it is necessary to change the way SMEs think to build business cooperation through the use of technology. The Fourth Industrial Revolution not only has tremendous potential to overhaul industry, but this is also certain to be a widespread view not only in government and academia but also in various walks of life [101].

The development of the innovations needed to support the increase in the productivity of small and medium enterprises are carried out through several strategic actions, namely: (1) increasing the skills, knowledge, and technological mastery of SMEs; (2) creating new products and improving the quality of products that have been marketed so far; (3) the transformation of business management towards the process of digitizing product marketing; and (4) building business cooperation in a sustainable manner. The four processes are carried out through a mentoring process by the government in the framework of fostering creativity and new ideas for small and medium enterprises. Entrepreneurship is a key element for SMEs to be competitive in the global market knowledge base towards economic growth, creativity, and innovation [102].

Three steps are needed in developing the ideas and creativity of small and medium enterprises towards increasing the productivity of economic enterprises, including: (1) the adaptation of the process, namely building creative product innovation to support flexibility and product originality through the process of thinking and behaving; (2) developing products that have creative value to produce new/original products or elaborate existing products in a more creative direction; (3) building the capacity of SME actors, both individually and in groups, to create new products according to consumer and market needs. There are three main strategic options based on customer experience, viz affordability and customization, and four distinct groups: customer enjoyment, multiple sources of differentiation, one-to-one marketing, and cost-effectiveness [103].

The development of ideas and creativity for SME players in Makassar City manifests in several stages: The first is the learning process, namely the design idea begins with deep learning to get an understanding of the basics of the design you want to make for business product development. This process requires a sound knowledge base of business design trends and developments. This means that this process can be carried out through various trainings and comparative studies to build different product designs from products that have been marketed by SMEs. The interaction of creativity, innovation and sustainability is gaining momentum, but more training and comparing existing products in the market is needed [104]. Second, the enlightenment of this process is carried out by building creative ideas based on the ideas of SME players to complete and perfect the product designs that have been produced. This means that the ideas that have been owned by SMEs are then refined into a complete set of product designs that will be produced and marketed. Third, the implementation of the design and verification of the resulting products, namely ensuring the design is correct towards solving the problems of SMEs in terms of increasing the competitiveness of the products produced to be marketed to consumers. One of the factors responsible for the failure of SMEs is the high volatility of global economic conditions [105]. 
Referring to the things that have been explained, efforts to increase the productivity of small and medium enterprises in Makassar City towards sustainability, economic stability, and the marketing of SMEs products will require further strategic steps in relation to business diversification and expansion, including: first, ease of licensing, through support for government policies and support for local regulations on SMEs. The ease of licensing is oriented towards the ease of obtaining formal legality, shortening the bureaucratic pathway, and making it easier for people to start developing economic business ventures. Second, business cooperation and product marketing, in this case in the context of global economic development, which will be dominated by small and medium enterprises. The role of the government is very strategic in the framework of facilitating SMEs to build business cooperation and product marketing through the use of technology towards industrial competition in the domestic and global markets. This means that the government has a role in protecting the market and facilitating the marketing of SMEs products. This effort is carried out through an intensive process of mentoring to SMEs players in marketing their products through e-marketing. Furthermore, technological and environmental challenges confront society with the need to change traditional approaches and management principles at regional and city levels [106].

Third, the creation of new market areas on a regional, national, and global scale through government support. This process is carried out through technological innovation, building product marketing networks, and strengthening the human resource capacity of SMEs. This step is carried out through the following efforts: (i) technical guidance for SMEs to enter the global market, (ii) the facilitation of global market intelligence, (iii) the curation of SMEs products with international standards, (iv) promotional cooperation abroad, and (v) optimizing bilateral and multilateral cooperation on SMEs product marketing. Furthermore, increasing the competitiveness of SMEs products is carried out through the following efforts: (1) development of joint production houses in small and medium industrial centers, including training, consultation and mentoring; (2) partnerships with large businesses, including transfer of knowledge, management and production technology as well as easy access to machine and technology facilities; (3) accelerated business development, including developing the incubation and acceleration of startup business ecosystem platform development (e.g., financing, logistics, marketing, innovation); (4) international standardization and certification, supporting SMEs (knowledge management, coaching, etc.) to obtain international standard certificates and enter the global market; (5) building a logistics system for SMEs, including: (i) improving supply chain connectivity at production centers, (ii) the development of imported raw materials and local raw material warehousing, (iii) developing warehousing that supports export consolidators, (iv) developing e-logistics that is integrated with e-commerce and fintech, and (vi) building facilities for reducing the postal costs for sending product samples.

Fourth, open innovation through smart cities to support the development of SMEs in Makassar City towards implementing an environment of innovation, empowerment, and participation of citizens, businesses, and other stakeholders in shaping the small and medium enterprises in Makassar City. In this context, the smart city is closely related to an open innovation strategy. Instilling a culture of innovation through training government managers and frontline workers is an important component in achieving a holistic approach and sustainable smart city transformations that can withstand leadership changes [107]. The meaning, the implementation of smart city is not only a government matter, but also the responsibility of the business world and SMEs towards the integration of information technology systems. Furthermore, the development of a smart city is oriented towards the inbound strategy of open innovation, which includes market-based innovation strategy, crowdsourcing, collaboration, and network building. The smart city will solve inherent problems while reducing expenses and improving quality of life. Through the technology of the Fourth Industrial Revolution, the advantages of the smart city are expected to be able to overcome city spending by platforming cities [108]. 
Fifth, the dynamics of the entrepreneurial cycle of open innovation, in this case developing business network relationships between companies and one another by giving value to cooperation between individuals with one another, whereas dynamic capability is more focused on interdependence with other companies so that the role of resources becomes an important element in SMEs achieving greater performance and maximizing profits, increasing income and welfare together. Currently small and medium enterprises (SMEs) play a leading role in most of the world's economies. For this reason, they seek technological competitiveness and improvement of their innovation activities [109].

Sixth, the micro and macro dynamics of open innovation with the quadruple helix model. The implementation of this model uses a positive synergy between government, industry, and universities (academics). The application of this model is directed at three roles in the development of innovation in a region, namely (i) the university as the center of research-based development activities, (ii) the industry as a provider of consumer needs, and (iii) the role of the government as a policy maker. These three things are an important part of increasing the productivity of SMEs in Makassar City in a sustainable manner. The implementation of the quadruple helix model refers to the findings of Ahonen and Hämäläinen [110], namely: (1) TH + users are Triple Helix which is extended with the community or users who provide information about their needs and experiences, for example by testing products; (2) a company-centered living laboratory model, where the community or users participate in each phase towards the development of ideas and innovation as the main driving force for business ventures being developed; (3) a living lab model that focuses on the public sector, where local government is at the center; and (4) a community-centered model, where the user determines which innovations are needed and developed. The implementation of these four models will lead to the creation of cooperation between the government, academics, and the SME community towards the sustainable economic growth of Makassar City.

Seventh, open innovation in SMEs in relation to trends, motivations and management challenges requires SMEs to encourage regional economic growth in Makassar City. Thus, the role of SMEs is an important element as a driver of entrepreneurship and economic development. Furthermore, the developing SMEs in Makassar City in the future will contribute positively to several things, including: (1) disseminating information related to the quality of the products produced; (2) optimizing the use of natural and human resources in the direction of increasing the productivity of economic enterprises; (3) optimizing demand for imported goods and fixing domestic prices for certain products and stimulating demand for domestic products towards product exports on the global market; (4) encouraging economic development towards increasing the standard of living of the community. Furthermore, global competencies and challenges due to advances in information technology will have an impact on the life and business flow of SMEs. This means that the existence of SMEs in Makassar City will require a transformation of business management and innovation strategies towards sustainable SMEs. To maintain an innovative work style, entrepreneurs need to build a unique identity to build an entrepreneurial identity [111].

Peter F. Drucker [112], stated that the main factors that support an organization to survive change include: (1) flexibility, in the sense that the economic business community must be flexible in making strategies. This means that in essence SMEs must be adaptive and ready to face changes in order to remain sustainable and stable. Businesses must be flexible in their implementation of the required strategies, namely policy, marketing, operations, and others; (2) providing facilities, in the sense that SMEs must be able to provide facilities to support business performance, including equipment, machinery, resources and technology. This means that increasing the productivity of SMEs will require facility support in facing global challenges; (3) managing knowledge. In this case SMEs have the ability to improvise changes by managing knowledge in a more productive direction; and (4) innovation. In this case SMEs have the ability to increase productivity, diversify and expand business. 
Eighth, regional asymmetrical knowledge capabilities and open innovation in relation to global marketing are global business-oriented activities that refer to the demand for certain products based on global standards. Furthermore, the relational view can be understood not only as a perspective for understanding organizations but also as a cultural way that can support network settings and interactions with other actors, as well as facilitate co-creation [113]. Thus, increasing the productivity of SMEs requires the importance of being able to compete by paying attention to the global environment. In order to make a production and consumption system for SME products in a sustainable manner, it is very important to further explore and support new business models in relation to product pricing, promotion, and distribution [114]. Thus, the performance of SMEs business activities will include the pricing, promotion, and distribution of products (goods and services) to customers/consumers for the purpose of making a profit. That is, global management is the evolution of management towards operationalization in the global market, namely exporting, negotiating franchises or licensing agreements, forming joint ventures, or making direct investments in other countries [115]. Furthermore, the factors that need to be considered in order to increase the competitiveness of SMEs to enter the global market are: (i) expected business volume, (ii) geographic scope, (iii) SMEs involvement in global marketing, (iv) sales volume and assets, (v) the product line and the nature of the products produced, and (vi) business competition in foreign markets. The six basic principles will ensure the stability of SME businesses going forward and contribute to the sustainable economic growth of Makassar City.

\section{Conclusions}

The development of SMEs in Makassar City has a strategic role and function in promoting economic growth and absorbing productive labor. To encourage an increase in business productivity, creativity and technological innovation are needed in the development of economic enterprises. The strategic steps needed for this are as follows: (1) empowering economic enterprises; (2) business training and guidance towards the use of technology; (3) training in financial management and business capital access through formal financial institutions; and (4) access to product marketing to reach potential markets. The business transformation, investment development, technological innovation, and management of SMEs will require the facilitation of institutional strengthening, modern business management, and investment cooperation within a framework of controlling production factors and business opportunities. SME diversification is closely related to the demands of consumer needs, while business differentiation is strongly influenced by the ability to build product marketing networks and a mastery of technology. The development of SMEs based on technological innovation will require efforts to rearrange policies, including (1) licensing and progressive manufacturing patterns that are oriented towards the introduction and mastery of superior product-based production technology; (2) building technological models, mastering more advanced production techniques, and continuing the pattern of integrating technological components into new products; (3) designing new, superior products after technology mastery integration by building products independently; (4) determining the market, in the sense that the government provides incentives and investment for the marketing of products developed in the community, especially by SMEs. Thus, SMEs will develop rapidly if supported by government policies, access to business capital, human resource capacity strengthening, and potential market access.

Four factors have a positive effect on the productivity development of SMEs in Makassar City: (i) technological innovation, (ii) business diversification, (iii) product marketing, and (iv) business stability. A weak mastery of technology in SMEs is influenced by several factors: (1) capabilities and expertise are limited, (2) operational costs are high, and (3) market guarantees for developing technology-based businesses are unsupportive. The SMEs that are developing in Makassar City can market their products, even if they are in limited quantities and only meet local needs. Business diversification is needed to support business stability and develop new business patterns towards economic business 
sustainability. Thus, economic growth, technological innovation, and business diversification have a significant effect on product marketing and the economic stability of SMEs in Makassar City.

The sustainability strategy of SMEs in Makassar City in relation to increasing business productivity is influenced by several factors, among others: (1) selection of the right location, which is highly dependent on the business being developed; (2) the use of social media, the role of which is a strategic choice in terms of product marketing; (3) business innovation, in a business with many competitors; and (4) financial planning, with a good administration system. The sustainability of SMEs in Makassar City will require several strategic steps that need to be considered: (1) manufacturing products according to consumer needs; (2) producing goods in small quantities to save costs and resources in an effort to eliminate in-process supplies of goods and waste, by using an evenly mixed production pattern; (3) eliminating waste on inventory, purchasing, and scheduling by using a card system in production; (4) improving production flow and building work discipline in the business culture; (5) improving product quality by maintaining control of the production process; (6) developing financial governance, product marketing, and human resource capacity strengthening, which are cross-functional in accordance with their levels and positions; (7) eliminating uncertainty by establishing relationships in the production and marketing processes; and (8) ensuring long-term maintenance by improving quality, increasing flexibility in placing orders for goods, ordering in small quantities, and continuously orienting towards a sustainable production process.

Because this study was conducted in a limited scope and focused on increasing the productivity of SMEs in relation to economic growth, it is advisable to carry out a follow-up study on the sustainability model of small and medium enterprises based on economic empowerment to complement the results of this study.

Author Contributions: B.S. conceived the study; B.S., F.M. and H.S. compiled the research; S.S., B.S. and H.A. completed the settlement; B.S., H.S. and M.I. processed the data; S.S., M.I. and H.A. contributed materials, methods, and analysis tools; B.S. and F.M. analyzed the data; S.S. and H.A. contributed to data checking; B.S., S.S., M.I. and H.A. wrote and revised the paper. All authors have read and published manuscript versions.

Funding: This research was funded by the University of Bosowa through the Research Center for Economic and Business Research LPPM, University of Bosowa, Makassar City.

Data Availability Statement: We fully support open scientific exchange through MDPI in sharing and archiving research data from this study. We fully comply with the provisions that have been set by referring to the established journal guidelines.

Acknowledgments: We are grateful for the participation of stakeholders in contributing ideas in carrying out this study. Thank you to the Bosowa Foundation for their support and financial assistance in carrying out this research.

Conflicts of Interest: The authors declare that there is no conflict of interest.

\section{References}

1. Stoica, O.; Roman, A.; Rusu, V.D. The Nexus between Entrepreneurship and Economic Growth: A Comparative Analysis on Groups of Countries. Sustainability 2020, 12, 1186. [CrossRef]

2. Maksum, I.R.; Sri Rahayu, A.Y.; Kusumawardhani, D. A Social Enterprise Approach to Empowering Micro, Small and Medium Enterprises (SMEs) in Indonesia. J. Open Innov. Technol. Mark. Complex. 2020, 6, 50. [CrossRef]

3. De Vasconcelos, M.V. Political Stability and Bank Flows: New Evidence. J. Risk Financ. Manag. 2020, 13, 56. [CrossRef]

4. Surya, B.; Syafri, S.; Hadijah, H.; Baharuddin, B.; Fitriyah, A.T.; Sakti, H.H. Management of Slum-Based Urban Farming and Economic Empowerment of the Community of Makassar City, South Sulawesi, Indonesia. Sustainability 2020, 12, 7324. [CrossRef]

5. Surya, B. Globalization, Modernization, Mastery of Reproduction of Space, Spatial Articulation and Social Change in Developmental Dynamics in Suburb Area of Makassar City (A Study Concerning on Urban Spatial Sociology). Asian Soc. Sci. 2014, 10, 261-268. [CrossRef]

6. United Nation. Pertumbuhan Ekonomi 11 Negara di Asia Tenggara pada. 2019. Available online: https:// databoks.katadata.co.i d/datapublish/2020/02/12/pertumbuhan-ekonomi-11-negara-di-asia-tenggara-pada-2019 (accessed on 12 April 2020). 
7. ASEAN Policy Brief. Economic Impact of COVID-19 Outbreak on ASEAN. ASEAN Integration Monitoring Directorate (AIMD) and Community Relations Division (CRD). 2020, pp. 1-17. Available online: https://asean.org/storage/2020/04/ASEAN-Policy -Brief-April-2020_FINAL.pdf (accessed on 12 August 2020).

8. Surya, B.; Ahmad, D.N.A.; Sakti, H.H.; Sahban, H. Land Use Change, Spatial Interaction, and Sustainable Development in the Metropolitan Urban Areas, South Sulawesi Province, Indonesia. Land 2020, 9, 95. [CrossRef]

9. Orhan, A.; Kirikkaleli, D.; Ayhan, F. Analysis of Wavelet Coherence: Service Sector Index and Economic Growth in an Emerging Market. Sustainability 2019, 11, 6684. [CrossRef]

10. Surya, B.; Syafri, S.; Sahban, H.; Sakti, H.H. Natural Resource Conservation Based on Community Economic Empowerment: Perspectives on Watershed Management and Slum Settlements in Makassar City, South Sulawesi, Indonesia. Land 2020, 9, 104. [CrossRef]

11. Meyer, N.; Auriacombe, C. Good Urban Governance and City Resilience: An Afrocentric Approach to Sustainable Development. Sustainability 2019, 11, 5514. [CrossRef]

12. Surya, B.; Saleh, H.; Suriani, S.; Sakti, H.H.; Hadijah, H.; Idris, M. Environmental Pollution Control and Sustainability Management of Slum Settlements in Makassar City, South Sulawesi, Indonesia. Land 2020, 9, 279. [CrossRef]

13. Bappenas. Modernisasi UMKM Atasi Permasalahan Masyarakat, Bantu Perekonomian Nasional. IDF. 2019. Available online: https:/ / www.bappenas.go.id/id/berita-dan-siaran-pers/idf-2019-modernisasi-umkm-atasi-permasalahan-masyarakat -bantu-perekonomian-nasional/ (accessed on 12 July 2020).

14. Prabowo, R.; Singgih, M.L.; Karningsih, P.D.; Widodo, E. New Product Development from Inactive Problem Perspective in Indonesian SMEs to Open Innovation. J. Open Innov. Technol. Mark. Complex. 2020, 6, 20. [CrossRef]

15. BPS Makassar City. Makassar City in Figures. 2019. Available online: https://makassarkota.bps.go.id/publication/2019/08/16/ 4ca03301b8e2b8414e33f6a3/kota-makassar-dalam-angka-2019.html (accessed on 3 February 2020).

16. Munizu, M. Pengaruh factor-Faktor eksternal dan internal terhadap kinerja usaha mikro dan kecil di Sulawesi Selatan. J. Manag. Entrep. 2010, 12, 33-41. [CrossRef]

17. Smith, S. Understanding and Acquiring Technology Assets for Global Competition. Technovation 2007, 27, 643-649. [CrossRef]

18. Hsien Wang, C.; Yuan Lu, L.; Bein Chen, C. Evaluating firm technological innovation capability under uncertainty. Technovation 2008, 28, 349-363. [CrossRef]

19. Xirogiannis, G.; Chytas, P.; Glykas, M.; Valiris, G. Intelligent Impact Assesment of HRM to Shareholder Value. Expert Syst. Appl. 2008, 35, 2017-2031. [CrossRef]

20. Surya, B.; Hadijah, H.; Suriani, S.; Baharuddin, B.; Fitriyah, A.T.; Menne, F.; Rasyidi, E.S. Spatial Transformation of a New City in 2006-2020: Perspectives on the Spatial Dynamics, Environmental Quality Degradation, and Socio-Economic Sustainability of Local Communities in Makassar City, Indonesia. Land 2020, 9, 324. [CrossRef]

21. Širá, E.; Vavrek, R.; Kravčáková Vozárová, I.; Kotulič, R. Knowledge Economy Indicators and Their Impact on the Sustainable Competitiveness of the EU Countries. Sustainability 2020, 12, 4172. [CrossRef]

22. Asian Development Bank. Fiscal Policy for Inclusive Growth; ADB Outlook; Asian Development Bank: Mandaluyong, Philippines, 2014; ISBN 978-92-9254-453-9. Available online: https:/ / www.adb.org/publications/asian-development-outlook-2014-fiscal-po licy-inclusive-growth (accessed on 25 July 2020).

23. Surya, B.; Hamsina, H.; Ridwan, R.; Baharuddin, B.; Menne, F.; Fitriyah, A.T.; Rasyidi, E.S. The Complexity of Space Utilization and Environmental Pollution Control in the Main Corridor of Makassar City, South Sulawesi, Indonesia. Sustainability 2020, 12, 9244. [CrossRef]

24. Alinska, A.; Filipiak, B.Z.; Kosztowniak, A. The Importance of the Public Sector in Sustainable Development in Poland. Sustainability 2018, 10, 3278. [CrossRef]

25. Saleh, H.; Surya, B.; Ahmad, D.N.A.; Manda, D. The Role of Natural and Human Resources on Economic Growth and Regional Development: With Discussion of Open Innovation Dynamics. J. Open Innov. Technol. Mark. Complex. 2020, 6, 103. [CrossRef]

26. Kim, D.; Lim, U. Social Enterprise as a Catalyst for Sustainable Local and Regional Development. Sustainability 2017, 9 , 1427. [CrossRef]

27. Roser, M. “Economic Growth". Published online at Our World in Data.org. 2013. Available online: https: / / ourworldindata.org / economic-growth (accessed on 5 July 2020).

28. Surya, B.; Saleh, H.; Hamsina, H.; Idris, M.; Ahmad, D.N.A. Rural Agribusiness-based Agropolitan Area Development and Environmental Management Sustainability: Regional Economic Growth Perspectives. Int. J. Energy Econ. Policy 2021, 11, 1-16. [CrossRef]

29. Spangenberg, J.H. Economic sustainability of the economy: Concepts and indicators. Int. J. Sustain. Dev. 2005, 8, 47-64. [CrossRef]

30. Agbloyor, E.K.; Abor, J.Y.; Adjasi, C.K.D.; Yawson, A. Private capital flows and economic growth in Africa: The role of domestic financial markets. J. Int. Financ. Mark. Inst. Money 2014, 30, 137-152. [CrossRef]

31. Kalemli-Ozcan, S.; Reshef, A.; Sørensen, B.E.; Yosha, O. Why does capital flow to rich states? Rev. Econ. Stat. 2010, 92, 769-783. [CrossRef]

32. Aoyagi, C.; Ganelli, G. Asia's quest for inclusive growth revisited. J. Asia Econ. 2015, 40, 29-46. [CrossRef]

33. Stiglitz, J.E. The origins of inequality and policies to contain it. Natl. Tax J. 2015, 68, 425-448. [CrossRef]

34. Stiglitz, J.E. America's Great Malaise and what to do about it. J. Policy Model. 2016, 38, 639-648. [CrossRef] 
35. Sawaya, A.; Bhero, S. Effect of simplified licensing on registration and formalizing of start-ups in Mozambique. Afr. J. Bus. Manag. 2018, 12, 542-554. [CrossRef]

36. Surya, B.; Saleh, H. Transformation of metropolitan suburban area (a study on new town development in Moncongloe-Pattalassang Metropolitan Maminasata). IOP Conf. Ser. Earth Environ. Sci. 2018, 202, 012027. [CrossRef]

37. Eliakis, S.; Kotsopoulos, D.; Karagiannaki, A.; Pramatari, K. Survival and Growth in Innovative Technology Entrepreneurship: A Mixed-Methods Investigation. Adm. Sci. 2020, 10, 39. [CrossRef]

38. Huang, Y.; Ge, Y.; Hu, W. Multiple Dynamic Mechanisms of Globalization: Alternatives to Capitalism. Sustainability 2019, 11, 5344. [CrossRef]

39. Phoosawad, S.; Fongsuwan, W.; Trimetsoontorn, J. Leadership, Management Skill and Organization Innovation Affecting Auto Parts Organization Performance. Res. J. Bus. Manag. 2014, 8, 70-88. [CrossRef]

40. Tang, S.; Wang, Z.; Yang, G.; Tang, W. What Are the Implications of Globalization on Sustainability? A Comprehensive Study. Sustainability 2020, 12, 3411. [CrossRef]

41. Li, H.; Sajjad, N.; Wang, Q.; Ali, A.M.; Khaqan, Z.; Amina, S. Influence of Transformational Leadership on Employees' Innovative Work Behavior in Sustainable Organizations: Test of Mediation and Moderation Processes. Sustainability 2019, 11, 1594. [CrossRef]

42. Shi, L.; Han, L.; Yang, F.; Gao, L. The Evolution of Sustainable Development Theory: Types, Goals, and Research Prospects. Sustainability 2019, 11, 7158. [CrossRef]

43. Soto-Acosta, P.; Cismaru, D.-M.; Vătămănescu, E.-M.; Ciochină, R.S. Sustainable Entrepreneurship in SMEs: A Business Performance Perspective. Sustainability 2016, 8, 342. [CrossRef]

44. Burhan, B. Metodologi Penelitian Sosial dan Ekonomi. In Format-format Kuantitatif dan Kualitatif untuk Studi Sosiologi, Kebijakan Publik, Komunikasi, Manajemen dan Pemasaran; Prenadamedia Group: Jakarta, Indonesia, 2015; p. 13220, ISBN 978-602-9413.75.5001.42.

45. Sugiono. Metode Penelitian Kuantitatif Kualitatif dan R dan D. Penerbit. Alfabeta. Bandung. 2011. Available online: ht tps:/ / openlibrary.telkomuniversity.ac.id/pustaka/10026/metode-penelitian-kuantitatif-kualitatif-dan-r-d.html (accessed on 6 January 2020).

46. Cochran, W.G. Sampling Techniques, 3rd ed.; John Willey \& Sons: New York, NY, USA, 1997; 448p, ISBN 978-0-471-162407. Available online: https://www.wiley.com/en-us/Sampling+Techniques\%2C+3rd+Edition-p-9780471162407 (accessed on 5 April 2020).

47. Rangkuti, F. Analisis Swot Teknik Membedah Kasus Bisnis: Reorientasi Konsep Perencanaan Strategis Untuk Menghadapi Abad Ke 21; Gramedia Pustaka Utama: Jakarta, Indonesia, 2006. Available online: https:/ /books.google.co.id/books?id=UHV8Z2SE57EC\&p rintsec $=$ frontcover\&hl=id\#v=onepage\& $\& \& \mathrm{f}=$ false (accessed on 5 February 2020).

48. Gherghina, S.C.; Botezatu, M.A.; Hosszu, A.; Simionescu, L.N. Small and Medium-Sized Enterprises (SMEs): The Engine of Economic Growth through Investments and Innovation. Sustainability 2020, 12, 347. [CrossRef]

49. Vermeulen, B.; Kesselhut, J.; Pyka, A.; Saviotti, P.P. The Impact of Automation on Employment: Just the Usual Structural Change? Sustainability 2018, 10, 1661. [CrossRef]

50. Matuzeviciute, K.; Butkus, M.; Karaliute, A. Do Technological Innovations Affect Unemployment? Some Empirical Evidence from European Countries. Economies 2017, 5, 48. [CrossRef]

51. Jia, C.; Tang, X.; Kan, Z. Does the Nation Innovation System in China Support the Sustainability of Small and Medium Enterprises (SMEs) Innovation? Sustainability 2020, 12, 2562. [CrossRef]

52. Khan, A.; Bibi, S.; Lorenzo, A.; Lyu, J.; Babar, Z.U. Tourism and Development in Developing Economies: A Policy Implication Perspective. Sustainability 2020, 12, 1618. [CrossRef]

53. Wolbers, M.H. Pattern of Labour Market Entry: A Comparative Perspective on School-to-Work Transitions in 11 European Countries. Acta Sociol. 2007, 50, 189-210. [CrossRef]

54. Koentjoro, S.; Gunawan, S. Managing Knowledge, Dynamic Capabilities, Innovative Performance, and Creating Sustainable Competitive Advantage in Family Companies: A Case Study of a Family Company in Indonesia. J. Open Innov. Technol. Mark. Complex. 2020, 6, 90. [CrossRef]

55. Zamfir, A.; Militaru, E.; Mocanu, C.; Lungu, E.O. School-to-work transition of higher education graduates in four European countries. Comp. A J. Comp. Int. Educ. 2020, 50, 36-52. [CrossRef]

56. Caraballo, M.A.; Buitrago, E.M. Ethnolinguistic Diversity and Education. A Successful Pairing. Sustainability 2019, 11, 6625. [CrossRef]

57. Witt, U. Capitalism as a complex adaptive system and its growth. J. Open Innov. Technol. Mark. Complex. 2017, 3, 12. [CrossRef]

58. Hong, K.; Kim, B. Organizational Resource, and Innovativeness to Sustainable Design Outsourcing Service. Sustainability 2020, 12, 5288. [CrossRef]

59. Kelley, T.; Kelley, D. Creative Confidence: Unleashing the Creative Potential within Us All; The Crown Publishing Group: Manhattan, NY, USA, 2013.

60. Luxemburg, R. The Accumulation of Capital: Section Three. The Historical Conditions of Accumulation. Chapter 26. The Reproduction of Capital and Its Social Setting. 2008. Available online: https://www.marxists.org/archive/luxemburg/1913/ac cumulation-capital/ch26.htm (accessed on 20 June 2020).

61. Surya, B. Spatial Interaction Pattern, and the Process of City Activity Formation System (Case study, Ternate City, Tidore Archipelago City and Sofifi City of North Maluku, Indonesia). Res. J. Appl. Sci. 2015, 10, 880-892. [CrossRef] 
62. Amar, M.Y. The influence of product differentiation strategy on operational performance at Small and Medium Enterprises (SMEs) in South Sulawesi, Indonesia. J. Econ. Bus. Account. Ventur. 2015, 18, 343. [CrossRef]

63. Setyowati, T.; Fadah, I. Differentiation Competitive Strategy in Winning Smes Advantage at Creative Industry in Jember. Int. J. Sci. Technol. Res. 2018, 7, 165-169. Available online: http:// repository.unej.ac.id/handle/123456789/84772 (accessed on 5 April 2020).

64. Yoon, J.; Hur, E.J.; Kim, M. An Analysis of the Factors on the Problem-Solving Competencies of Engineering Employees in Korea. Sustainability 2020, 12, 1677. [CrossRef]

65. Horváthová, P.; Mikušová, M.; Kashi, K. Comparison of Human Resources Management in Non-Family and Family Businesses: Case Study of the Czech Republic. Sustainability 2020, 12, 5493. [CrossRef]

66. He, J.; Chen, H.; Sheng Tsai, F. Strategy Orientation, Innovation Capacity Endowment, and International R\&D Intensity of Listed Companies in China. Sustainability 2020, 12, 344. [CrossRef]

67. Na, Y.K.; Kang, S.; Jeong, H.Y. The Effect of Market Orientation on Performance of Sharing Economy Business: Focusing on Marketing Innovation and Sustainable Competitive Advantage. Sustainability 2019, 11, 729. [CrossRef]

68. Jahanshahi, A.A.; Nawaser, K.; Khaksar, S.M.S.; Kamalian, A.R. The Relationship between Government Policy and the Growth of Entrepreneurship in the Micro, Small \& Medium Enterprises of India. J. Technol. Manag. Innov. 2011, 6, 66-76. [CrossRef]

69. Perez-Gomez, P.; Arbelo-Perez, M.; Arbelo, A. Profit efficiency and its determinants in small and medium-sized enterprises in Spain. BRQ Bus. Res. Q. 2018, 21, 238-250. [CrossRef]

70. Gunasekaran, A.; Rai, B.K.; Griffin, M. Resilience, and competitiveness of small and medium size enterprises: An empirical research. Int. J. Prod. Res. 2011, 49, 5489-5509. [CrossRef]

71. Kiron, D.; Unruh, G.; Kruschwitz, N.; Reeves, M.; Rubel, H.; Felde, A.M. Corporate Sustainability at a Crossroads: Progress Toward Our Common Future in Uncertain Times. MIT Sloan Manag. Rev. 2017. Available online: https://sloanreview.mit.edu/pr ojects / corporate-sustainability-at-a-crossroads / (accessed on 1 July 2020).

72. Ioana Munteanu, A.; Bibu, N.; Nastase, M.; Cristache, N.; Matis, C. Analysis of Practices to Increase the Workforce Agility and to Develop a Sustainable and Competitive Business. Sustainability 2020, 12, 3545. [CrossRef]

73. Nigri, G.; Del Bald, M. Sustainability Reporting and Performance Measurement Systems: How do Small- and MediumSized Benefit Corporations Manage Integration? Sustainability 2018, 10, 4499. [CrossRef]

74. Masocha, R. Does Environmental Sustainability Impact Innovation, Ecological and Social Measures of Firm Performance of SMEs? Evidence from South Africa. Sustainability 2018, 10, 3855. [CrossRef]

75. Xin, L.; Tang, F.; Zhang, S.; Pan, Z. Social Capital, and Sustainable Innovation in Small Businesses: Investigating the Role of Absorptive Capacity, Marketing Capability and Organizational Learning. Sustainability 2020, 12, 3759. [CrossRef]

76. Shankar, K.M.; Kannan, D.; Kumar, P.U. Analyzing sustainable manufacturing practices-A case study in Indian context. J. Clean. Prod. 2017, 164, 1332-1343. [CrossRef]

77. Gamage, S.K.N.; Ekanayake, E.M.S.; Abeyrathne, G.; Prasanna, R.; Jayasundara, J.; Rajapakshe, P.S.K. A Review of Global Challenges and Survival Strategies of Small and Medium Enterprises (SMEs). Economies 2020, 8, 79. [CrossRef]

78. Dushi, N.S.; Dana, L.P.; Ramadani, V. Entrepreneurial marketing dimensions and SMEs performance. J. Bus. Res. 2019, 100, 86-99. [CrossRef]

79. Surya, B. Optimization of Function and Role of Traditional Markets in Urban Development System of Ketapang City (A Case Study: Range Sentap Market, Delta Pawan Subdistrict, Ketapang City). World Appl. Sci. J. 2015, 33, 1457-1471. [CrossRef]

80. Park, S.; Jun, S. Statistical Technology Analysis for Competitive Sustainability of Three Dimensional Printing. Sustainability 2017, 9, 1142. [CrossRef]

81. Gironés, E.S.; Est, R.; Verbong, G. The role of policy entrepreneurs in defining directions of innovation policy: A case study of automated driving in the Netherlands. Technol. Forecast. Soc. Chang. 2020, 161, 120243. [CrossRef]

82. Dvouletý, O. Effects of Soft Loans and Credit Guarantees on Performance of Supported Firms: Evidence from the Czech Public Programme START. Sustainability 2017, 9, 2293. [CrossRef]

83. Surya, B. The Dynamics of Spatial Structure and Spatial Pattern Changes at the Fringe Area of Makassar City. Indones. J. Geogr. 2015, 47, 11-19. [CrossRef]

84. Kang, S.; Kue Na, Y. Effects of Strategy Characteristics for Sustainable Competitive Advantage in Sharing Economy Businesses on Creating Shared Value. Sustainability 2020, 12, 1397. [CrossRef]

85. Surya, B. Change Phenomena of Spatial Physical in the Dynamics of Development in Urban Fringe Area. Indones. J. Geogr. 2016, 48, 118-134. [CrossRef]

86. Prasanna, R.; Jayasundara, J.; Gamage, S.K.N.; Ekanayake, E.; Rajapakshe, P.S.K.; Abeyrathne, G. Sustainability of SMEs in the Competition: A Systemic Review on Technological Challenges and SME Performance. J. Open Innov. Technol. Mark. Complex. 2019, 5, 100. [CrossRef]

87. Surya, B.; Saleh, H.; Remmang, H. Economic Gentrification and Sociocultural Transformation Metropolitan Suburban of Mamminasata. J. Eng. Appl. Sci. 2018, 13, 6072-6084. [CrossRef]

88. Meré, J.O.; Remón, T.P.; Rubio, J. Digitalization: An Opportunity for Contributing to Sustainability from Knowledge Creation. Sustainability 2020, 12, 1460. [CrossRef]

89. Kook, S.H.; Kim, K.H.; Lee, C. Dynamic Technological Diversification and Its Impact on Firms' Performance: An Empirical Analysis of Korean IT Firms. Sustainability 2017, 9, 1239. [CrossRef] 
90. Seelos, C.; Mair, J. Social entrepreneurship: Creating new business models to serve the poor. Bus. Horiz. 2005, 48, 241-246. [CrossRef]

91. Coghlan, C.; Labrecque, J.; Ma, Y.; Dubé, L. A Biological Adaptability Approach to Innovation for Small and Medium Enterprises (SMEs): Strategic Insights from and for Health-Promoting Agri-Food Innovation. Sustainability 2020, 12, 4227. [CrossRef]

92. Eravia, D.; Handayani, T. The Opportunities and Threats of Small and Medium Enterprises in Pekanbaru: Comparison between SMEs in Food and Restaurant Industries. Procedia Soc. Behav. Sci. 2015, 169, 88-97. [CrossRef]

93. Diabate, A.; Sibiri, H.; Wang, L.; Yu, L. Assessing SMEs' Sustainable Growth through Entrepreneurs' Ability and Entrepreneurial Orientation: An Insight into SMEs in Côte d'Ivoire. Sustainability 2019, 11, 7149. [CrossRef]

94. García, M.R.; García, M.G.; Castillo, A.C. An Overview of Ecopreneurship, Eco-Innovation, and the Ecological Sector. Sustainability 2019, 11, 2909. [CrossRef]

95. Krizanova, A.; Lăzăroiu, G.; Gajanova, L.; Kliestikova, J.; Nadanyiova, M.; Moravcikova, D. The Effectiveness of Marketing Communication and Importance of Its Evaluation in an Online Environment. Sustainability 2019, 11, 7016. [CrossRef]

96. Surya, B. Spatial Articulation and Co-Existence of Mode of Production in the Dynamics of Development at the Urban Fringe of Makassar City. J. Eng. Appl. Sci. 2015, 10, 214-222. [CrossRef]

97. Cantele, S.; Vernizzi, S.; Campedelli, B. Untangling the Origins of Sustainable Commitment: New Insights on the Small vs. Large Firms' Debate. Sustainability 2020, 12, 671. [CrossRef]

98. Liu, Y.; Dijst, M.; Geertman, S.; Cui, C. Social Sustainability in an Ageing Chinese Society: Towards an Integrative Conceptual Framework. Sustainability 2017, 9, 658. [CrossRef]

99. Surya, B.; Ruslan, M.; Abubakar, H. Inequility of Space Reproduction Control and Urban Slum Area Management Sustainability (Case Study: Slum Area of Buloa Urban Village in Makassar City). J. Eng. Appl. Sci. 2018, 13, 6033-6042. [CrossRef]

100. Phan, A.C.; Nguyen, H.T.; Nguyen, H.A.; Matsui, Y. Effect of Total Quality Management Practices and JIT Production Practices on Flexibility Performance: Empirical Evidence from International Manufacturing Plants. Sustainability 2019, 11, 3093. [CrossRef]

101. Muljani, N.; Ellitan, L. Developing Competitiveness in Industrial Revolution 4.0. Int. J. Trend Res. Dev. 2019, 6, 1-3. Available online: http:/ / www.ijtrd.com/papers/IJTRD20721.pdf (accessed on 5 August 2020).

102. Boldureanu, G.; Ionescu, A.M.; Bercu, A.M.; Bedrule-Grigoruță, M.V.; Boldureanu, D. Entrepreneurship Education through Successful Entrepreneurial Models in Higher Education Institutions. Sustainability 2020, 12, 1267. [CrossRef]

103. Stancu, A.; Filip, A.; Rosca, M.I.; Ionită, D.; Căplescu, R.; Cânda, A.; Rosca, L.D. Value Creation Attributes-Clustering Strategic Options for Romanian SMEs Value Creation Attributes-Clustering Strategic Options for Romanian SMEs. Sustainability 2020, 12, 7007. [CrossRef]

104. Brem, A.; Díaz, R.P. Creativity, Innovation, Sustainability: A Conceptual Model for Future Research Efforts. Sustainability 2020, 12, 3139. [CrossRef]

105. Tang, G.X.; Park, K.; Agarwal, A.; Liu, F. Impact of Innovation Culture, Organization Size and Technological Capability on the Performance of SMEs: The Case of China. Sustainability 2020, 12, 1355. [CrossRef]

106. Tolstykh, T.; Gamidullaeva, L.; Shmeleva, N.; Wozniak, M.; Vasin, S. An Assessment of Regional Sustainability via the Maturity Level of Entrepreneurial Ecosystems. J. Open Innov. Technol. Mark. Complex. 2021, 7, 5. [CrossRef]

107. Myeong, S.; Kim, Y.; Ahn, M.J. Smart City Strategies-Technology Push or Culture Pull? A Case Study Exploration of Gimpo and Namyangju, South Korea. Smart Cities 2021, 4, 41-53. [CrossRef]

108. Yun, Y.; Lee, M. Smart City 4.0 from the Perspective of Open Innovation. J. Open Innov. Technol. Mark. Complex. 2019, 5, 92. [CrossRef]

109. Juárez, L.E.V.; Vergara, M.C. Technological Capabilities, Open Innovation, and Eco-Innovation: Dynamic Capabilities to Increase Corporate Performance of SMEs. J. Open Innov. Technol. Mark. Complex. 2021, 7, 8. [CrossRef]

110. Ahonen, L.; Hämäläinen, T. CLIQ: A Practical Approach to the Quadruple Helix and More Open Innovation. In Sustaining Innovation: Collaboration Models for a Complex World, Innovation, Technology, and Knowledge Management; MacGregor, S.P., Carleton, T., Eds.; 2012. Available online: https:/ /link.springer.com/chapter/10.1007\%2F978-1-4614-2077-4_2 (accessed on 5 October 2020).

111. Zhou, J.; Xu, X.; Li, Y.; Liu, C. Creative Enough to Become an Entrepreneur: A Multi-Wave Study of Creative Personality, Education, Entrepreneurial Identity, and Innovation. Sustainability 2020, 12, 4043. [CrossRef]

112. Drucker, P.F. Manajemen: Tugas, Tanggung Jawab dan Praktek; PT Gramedia: Jakarta, Indonesia, 1999. Available online: http:/ / library.um.ac.id/free-contents/index.php/buku/detail/manajemen-tugas-tanggung-jawab-praktek-buku-i-peter-f-d rucker-diterjemahkan-oleh-sitor-situmorang-dkk-15724.html (accessed on 10 October 2020).

113. Rupo, D.; Perano, M.; Centorrino, G.; Sanchez, A.V. A Framework Based on Sustainability, Open Innovation, and Value Cocreation Paradigms-A Case in an Italian Maritime Cluster. Sustainability 2018, 10, 729. [CrossRef] 
114. Oksana Mont, D.B.; Schoonover, H. Consumer Acceptance and Value in Use-Oriented Product-Service Systems: Lessons from Swedish Consumer Goods Companies. Sustainability 2020, 12, 8079. [CrossRef]

115. Tjiptono, F.G. Chandra. Service, Quality, E Satisfaction; Penerbit Andi: Yogyakarta, Indonesia, 2005; ISBN 978-979-29-5384-8. Available online: http:/ / www.library.usd.ac.id/web/index.php?pilih=search\&p=1\&q=0000131247\&go=Detailhttp:/ /www.li brary.usd.ac.id/web/index.php?pilih=search\&p=1\&q=0000131247\&go=Detail (accessed on 5 July 2020). 